\title{
Economic Reforms, External Liberalization and Macroeconomic Performance in Vietnam
}

\author{
Huong Le \\ Department of Economics, Colorado State University, USA \\ School of International Business and Economics, Foreign Trade University \\ E-mail: huongle@colostate.edu \\ Tel: +1-970-212-6011
}

\begin{abstract}
This paper examines the macro-economic performance of Vietnam through the six phases of Doi Moi reform and analyzes the impact of external liberalization on economic growth, aggregate demand, employment and income distribution. The decomposition of aggregate demand suggests that private investment was the most important determinant of Vietnamese economic growth during the period of 1994 - 2011, while government expenditure has become more significant since 2005, and the external sector together with government expenditure are the important driving factors of Vietnamese economic growth since 2012. The decomposition of overall labor productivity highlighted the fact that sectoral productivity growth of the service sector plays an important role in the improvement of overall labor productivity in Vietnam.
\end{abstract}

Keywords: Macroeconomics, economic reform, economic growth, external liberalization aggregate demand, employment.

JEL codes: E1, E6

\section{Introduction}

In the past three decades, Vietnam has experienced "one of the highest rates of economic growth and poverty reduction in the world" (Vandemoortele and Bird, 2011, p 3). The successful implementation of its extensive economic and political reforms, called Doi Moi - "a comprehensive program of external and domestic reforms that placed the country on the path to a more market-oriented economy"- in 1986, transformed the nation from a closed and centralized economy to a marketoriented system (Le, 2006, p 456). Vietnam also became a full-fledged member of the international community. Vietnam signed several trade agreements and joined regional associations such as the trade agreement with the European Union (EU) in 1992; normalized diplomatic relations with the United States in 1995; joined the Association of Southeast Asian Nations (ASEAN) and the ASEAN Free Trade Agreement (AFTA) in 1995; became a member of the Asia Pacific Economic Cooperation Forum (APEC) in 1998; signed a Bilateral Trading Agreement (BTA) with the United States in 2001 and became a member of the World Trade Organization (WTO) in 2007 after eleven years of negotiations (Nguyen et al, 2012). Vietnam has enjoyed an improvement in its diplomatic and political relationship with more than 170 countries in the world.

After 30 years of its economic reforms (Doi Moi), Vietnam has now integrated with the global community (Tsuboi, 2007) and become one of the fastest growing economies in the South East Asia (Bhatt, 2013) with a gross domestic product (GDP) of \$202.62 billion and per capital GDP of \$2,115 in 2016 (UN dataset, 2016). High rates of economic growth and an impressive macroeconomic 
performance have also been observed in Vietnam since its economic opening in the 1990s. Trade openness measured by the sum of exports and imports as a percentage of GDP rose to 169 percent in $2014^{39}$ while FDI inflows have been increasing substantially since the approval of the first Law on Foreign Investment in 1987. The poverty rate has been reduced from 37.4 percent in 1998 to 14.2 percent in 2010 and 7 percent in 2015 (GSO dataset, 2015). The thirty-year successful economic reforms have also led to a notable human capital development performance. The human development index (HDI) value in Vietnam had increased by about 40 percent during the period 1990-2012 (OECD, 2014). The implementation of Doi Moi has transformed the nation from an agriculture-oriented economy to a modern industry-oriented system, bringing about a high rate of growth of gross industrial output (GIO) (Statistical Yearbook of Vietnam, 2014).

In view of these developments, the questions arises - what are the main mechanisms driving the spectacular performance of Vietnamese economy since its reform? What lies behind the increasing trend in economic growth of Vietnam recently, and to what extent and how is Vietnamese economic growth related to its comprehensive reforms and external liberalization? This essay investigates the macro-economic performance of Vietnam through the six phases of Doi Moi reform and analyzes the impact of external liberalization on economic growth, aggregate demand, employment and distribution.

The paper is structured into six sections. An overview of the Doi Moi Policy and its major policies which has transformed the nation from a centralized and closed economy to an open and market-oriented system is introduced in section 2. Section 3 is an overview of the trends in external liberalization and macroeconomic performance in Vietnam since the reforms. The specific impact of effective demand and employment are discussed in section 4 and section 5 respectively. Section 6 is the concluding remarks and recommendations.

\section{Overview of Economic Reform in Vietnam}

\subsection{The Introduction of Vietnamese Economic Reform}

After almost a century of conflict through the French and American wars, Vietnam faced a severe economic crisis, near famine, hyperinflation after unification in 1975 (Vuong, 2014). The American trade embargo which prevented trade with the western economies, together with the collapse and disintegration of the trading system of the Soviet Union Bloc in 1989 worsened the economic crisis. These severe economic conditions forced the Communist Party and Vietnamese government to embrace New Economic Policy and launch extensive reforms.

The Vietnamese economic reforms (the Doi Moi Policy) was adopted after the $6^{\text {th }}$ National Congress of the Communist Party of Vietnam in 1986, however the Policy only got fully on track from late 1989. In Vietnamese, "doi moi" means "renovation". The Doi Moi policy refers to a comprehensive program of external and domestic reforms that transformed the economy from closed and centralized to an open and market-oriented one. In other words, "Doi Moi was a policy that abandoned doctrinaire socialist theories, introduced a market economy and opened the country to the global economy" (Tsuboi, 2007, p 1). The policy was adopted and commenced subsequently to the reforms and openness under Chinese leadership of Deng Xiao Ping in 1978 and Perestrika reforms of the Soviet Union that significantly changed the fundamentals of the socialism of the past (Tsuboi, 2007). As a result, the closed and centrally planned economy has been replaced by a particular kind of market-oriented system, while adopting the concept of a multi-sectoral economy, with open-door policies towards international trade and investment, and recognized private sectors, while emphasizing the state sectors.

The $7^{\text {th }}$ National Congress of the Communist Party of Vietnam in 1991 deepened and strengthened the Doi Moi Policy in 1986. It was followed by the Amended Constitution in 1992 which enshrined the Doi Moi Policy in the set of "supreme laws" of the nation in statutory form. The

\footnotetext{
${ }^{39}$ Author's calculation from export and import's dataset of GSO and GDP's dataset of United Nations.
} 
Amended Constitution introduced the economic policy of a market system; recognized freedom in proprietary rights and private sector in the economy, approved and recognized long-term land-use rights and encouraged joint enterprises with foreign countries. Since the adoption of Doi Moi Policy in 1986, Vietnam has embraced massive economic and political reforms which are the most important catalyst for dramatic changes and economic growth and development in Vietnam. The Vietnamese government has introduced a host or other economic and political policies depending on real economic situations. Table 1 introduces the milestones of the Doi Moi Policy from 1986 to present day.

In short, the Doi Moi Policy is a package of comprehensive economic reforms. It included reforms in agriculture, where the abandonment of state-led land collectivization and encouragement of privatization gave more rights to farmers; improvement of price-control by the gradual reduction of subsidies for state enterprises, encouragement of private business in all sectors and allowing commodity prices to be set up by the market and integration to the global trade through an export-led strategy (Keough, 2016).

\subsection{The Major Policy Phases of Doi Moi}

Table 1: Milestones of the Doi Moi Policy from 1986 to Present Day

\begin{tabular}{|c|c|}
\hline Year & Significant Events \\
\hline 1986 & - The Sixth National Congress Meeting of the Communist Party of Vietnam launched the Doi Moi Policy. \\
\hline 1987 & $\begin{array}{l}\text { - Land Law was introduced } 1^{\text {st }} \text { time (amended in } 1993,1998,2001,2003 \text { and 2013) } \\
\text { - Foreign Investment Law was introduced } 1^{\text {st }} \text { time (amended in 1990, 1992, 1995, 1996, } 20002005,2009 \text { ) }\end{array}$ \\
\hline 1988 & - Resolution 10 in agricultural management was adopted, abandoning collectivization \\
\hline 1990 & $\begin{array}{l}\text { - Corporate Law and Private Enterprise Law were launched to stimulate private business } \\
\text { - The ideas about privatization of state-owned enterprise was introduced } \\
\text { - One-tiered banking system was changed into a two-tiered one }\end{array}$ \\
\hline 1991 & - Soviet Union Bloc collapsed, the Communist Party of Vietnam decided to remain with the socialist ideology \\
\hline 1992 & $\begin{array}{l}\text { - The Amended Constitution was introduced, which recognized the role of private sector in the economy. } \\
\text { - A trade agreement with the European Union (EU) was signed }\end{array}$ \\
\hline 1995 & $\begin{array}{l}\text { - Joined the Association of Southeast Asian Nations (ASEAN) and the agreements of the ASEAN Free Trade } \\
\text { Agreement (AFTA) } \\
\text { - Normalized the diplomatic relations with the United States }\end{array}$ \\
\hline 1998 & - Became a member of the Asia Pacific Economic Cooperation Forum (APEC) \\
\hline 2000 & - The Enterprise Law was enacted \\
\hline 2001 & $\begin{array}{l}\text { - Signed the Bilateral Trading Agreement (BTA) with the United States. } \\
\text { - New Socioeconomic Development Strategy for 2001-2010 and five-year plan to } 2005 \text { was introduced } \\
\text { - Decree 44/2001/ND-CP allows all kinds of companies to export and import all permissible goods was passed }\end{array}$ \\
\hline 2002 & - The Fifth Party Plenum gives Party members the right to own private business. \\
\hline 2007 & - Became a member of the World Trade Organization (WTO) after eleven long years of negotiations. \\
\hline 2009 & - Vietnamese government released the stimulus package of US\$8 billion after the global financial crisis in 2008 \\
\hline 2010 & $\begin{array}{l}\text { - Became a negotiating party of the Trans Pacific Partnership (TPP) agreement in November, 2010. After the } \\
\text { US withdrew from this agreement, the future of this agreement is now being reconsidered. }\end{array}$ \\
\hline 2011 & - Resolution No.11/NQ-CP was approved on 02/24/2011 to control inflation and stabilize the macroeconomy. \\
\hline 2013 & $\begin{array}{l}\text { - An economic stimulus package of VND30,000 billion (approximately USD1.5 billion) was approved to revive } \\
\text { and stimulate the real estate market. }\end{array}$ \\
\hline 2016 & $\begin{array}{l}\text { - Approved the Socio-Economic Development Plan (SEDP) for 2016-2020 in 4/2016, which emphasized the } \\
\text { importance of structural reforms, environmental sustainability, social equity and highlighted emerging issues } \\
\text { of macroeconomic stability. }\end{array}$ \\
\hline
\end{tabular}

Source: Author's compilation

Since the adoption of Doi Moi Policy in 1986 by the $6^{\text {th }}$ National Congress of the Communist Party of Vietnam in 1986, Vietnam has integrated more fully with international economy and successfully modernized its economy which was mostly based on agriculture, and also produced 
dramatic growth and poverty reduction. The following section set out the major policies of six different phases of thirty years of the Doi Moi Policy (1986-2016).

Phase I: The first adoption of comprehensive reforms (1986 - 1993)

The first phase from 1986 to 1993 was marked by the adoption of the Doi Moi Policy during the $6^{\text {th }}$ National Congress of the Communist Party of Vietnam in December 1986. During this phase, the Communist Party of Vietnam started implementing the Doi Moi Policy which has embraced multisectoral economic mechanisms with open door policies towards trade, encouraging private sectors while continuing to emphasize the state sector.

The introduction of the Foreign Investment Law in 1987 strengthened the effort of Vietnamese government in opening their economy to the global community. As a result, Vietnam enjoyed continuous inflows of Foreign Direct Investment (FDI) which has been regarded as the main catalyst of its economy.

An important thrust of Doi Moi Policy is the recognition of the private sector and the "decooperatization" as well as the "decollectivization" of agriculture. As a result, during the first phase, a centrally collective model of the agriculture production system was gradually replaced by the private ownership of land. For example, in 1988, Resolution 10 in agricultural management was adopted, abandoning collectivization. Together with the introduction of Land Law in 1987, Resolution 10 granted and recognized longer-term land use rights for famers who could now exchange, mortgage, transfer, rent and inherit land. In 1989, Vietnam became the second largest rice exporter in the world (Statistical Year Book of Vietnam, 1990).

In 1987, Vietnamese government launched policies to strengthen the financial markets by eliminating subsidies and imposing budget controls. It also started to liberalize the exchange rate and pricing system, so as to narrow the price disparity between free market and official market. A new currency was introduced in 1988, and the central treasury was established in 1987. Vietnamese government also separated commercial and central banking functions by the New Banking Laws in 1989.

The disintegration of the main Vietnamese trading partner - the Soviet Union Bloc in 1990 also forced the government to find new trading partners. The Corporate Law and Private Enterprise Law initiated in 1990 allowed private enterprises and private property rights. As a result, the number of start-up entrepreneurial enterprises increased by 17,400 in 1994 (Vuong, 2014). Moreover, starting from 1991, Vietnamese government also gave private enterprises permission to directly export and import goods and services.

In 1992, a constitutional amendment was passed, officially recognizing human rights in all civil, political, social, economic and cultural fields including the right of access to information; the right to assembly, the right to association; the right to free movement and residence in the country, the right to demonstrate in accordance with law; the right to follow or not follow any religion. The constitution also recognized the multi-sectoral economy and deepened the Doi Moi Policy by reaffirming the leading role of the Communist Party of Vietnam with socialist orientations.

Phase II: The period of political and economic integration: Implementing the Doi Moi Policy $(1994-1997)$

The Communist Party of Vietnam continued extensive reforms in the second phase (19941997), the most active and busiest stage of the Doi Moi Policy. Vietnamese government continued further economic integration and diplomatic relations within the region and with the rest of the world. The second phase of Doi Moi was marked by the lifting of U.S trade embargo and the normalization of diplomatic relation with the United States in 1995. Vietnam joined the Association of Southeast Asian Nations (ASEAN); signed the agreements of the ASEAN Free Trade Agreement (AFTA) in 1995, cementing the international integration of its economy.

In the second phase, the Law on State-Owned Enterprises (SOE) was enacted. This law placed the SOEs under direct supervision of Ministry of Finance in 1995. However, the leading role of the SOEs sector was still being debated among communist party members. During the Eighth Party 
Congress in 1996, some communist members agreed to remain the leading role of the SOEs sector, while the others pushed the shift from state-own enterprises to non-state-owned enterprises.

The state budget was also under better management by Law on the State Budget, initiated in 1996. The State Budget Law defines tax and expenditure responsibilities of the different levels of government. Preferential credit for selected sectors and disadvantaged regions was provided by the National Investment Fund.

The Vietnamese government also used temporary import bans for selected goods such as cement, steel, paper, beer, sugar and confectionary to support the domestic market. They have given more rights to private enterprises to export rice but under certain conditions. The amended Law on Foreign Investment reduces import duty exemptions for FDI companies and clarifies some investment policies. Besides the open-door policy, Vietnamese government has also attempted to stimulate domestic investment through the Law on Promotional of Domestic Investment in 1995.

After the Asian financial crisis in 1997, Vietnamese policy-makers and the newly opened market-oriented economic mechanisms faced new challenges.

Phase III: Facing with the first economic turmoil since Doi Moi Policy (1998 - 2000)

The Doi Moi policy was deepened in the third phase from 1998-2000. The country became a member of the Asia Pacific Economic Cooperation Forum (APEC) in 1998 two years after applying for membership. However, the market-oriented economy was hurt by the Asian financial crisis in 1997 and more active policy intervention was needed. In response to the crisis, the government started applying non-tariff measures and exchange-rate controls to restrict imports and protect domestic production in late 1998. New regulations were introduced to encourage and support exports such as the New Enterprise Law in 1999 and Decree 57 which gives more rights for export companies. For example, companies that were owned by foreign investors were permitted to export goods not specified in investment licenses.

The most significant achievements of the third phase was the introduction of a formal stock market in Ho Chi Minh city in 2000 and the commitment of the Communist Party of Vietnam at the Tenth Party Plenum to pursue the Doi Moi Policy in which the first priority was to continue with regional and global integration.

Phase IV: Recovery from the Asian crisis and economic boom (2001 - 2007)

The fourth phase of Doi Moi Policy was marked by the US-Vietnam bilateral trading agreement (the BTA) in 2001, which opened up new prospects and opportunities for bilateral trade. The opendoor policies towards international trade and investment of the Vietnamese government was strengthened by its relationships with the IMF and the World Bank who restarted structural adjustment lending to Vietnam in 2001.

The Ninth National Party Congress in 2001 reaffirmed the leading role of the state government while recognizing the role of the private domestic sectors and foreign investors in economic development. Those policies facilitated restructuring and corporatization of state enterprises under the Enterprise Law. Enterprises, individuals, cooperatives and foreign investors have been permitted to export and import all permissible commodities by Decree 44/2001/ND-CP in 2001. Since 2002, communist party members have been permitted to establish and own private businesses.

In January 2007, Vietnam has officially become a full member of the World Trade Organization (WTO) after eleven years long of negotiations. This has brought emerging opportunities and challenges for its economy and people.

Phase V: Market-oriented economy and the global financial crisis (2008 - 2012)

The Vietnamese economy has been on the path to a market-oriented system since 1986. It has fully integrated with the global economy after becoming an official member of the World Trade Organization. This has also made the economy vulnerable to the global crisis. Vietnam's unstable macroeconomy with two-digit inflation in 2008 together with spillover effect of the global crisis made 
the stock market bubble burst in 2009 resulting a dramatic decrease in VN-index ${ }^{40}$ from the peak of 1170 points in March 2007 to less than 250 points in February in 2009. The boom of stock market bubble also pulled down the real estate market in 2010.

The contemporary state-run conglomerate model also poses problems of inefficiency, corruption and crony capitalism. The macro economy faced a chaotic period of high inflation, budget deficit, a decline in foreign exchange reserve, unformulated and mismanaged fiscal and monetary policies, high unemployment and sluggish commercial activities in late 2012 (Vuong, 2014). Many state-run conglomerates such as Vinashin have suffered overwhelming losses, growing debt burdens, or corruption scandal.

Despite its vulnerable macroeconomy, Vietnamese government has been continuing their opendoor policies and been very active with regional integration. Vietnam has been a full member in the negotiations on the Trans-Pacific Partnership Agreement (TPP) which covers almost sectors of the economy included trade, investment, intellectual property rights, labor and environment since November 2010, until the recent stalling of the negotiations.

Phase VI: Stabilization of the market-oriented economy: Lessons from the global financial crisis (2013 - present)

Faced with the global financial crisis and the slump in the domestic stock market, banking and real estate sectors, as well as overwhelming business closures during the 2007- 2012 phase, Vietnamese government decided to reorient policy toward controlling inflation and stabilizing the macroeconomy, using direct tools and comprehensive monetary policies. For example, since 2011, the Vietnamese State Bank has devalued the national currency seven times. Resolution No.11/NQ-CP was approved on 02/24/2011 to control inflation and stabilize the macroeconomy. In 2013, an economic stimulus package of VND 30,000 billion (about USD1.5 billion) was approved to revive the real estate market after its 2011 collapse.

The Amended Constitution in 2013 was also one of the most remarkable transformations in this phase. This is the first time, the Vietnamese Constitution has determined subjects of human rights to "everyone", not only "citizen", which removed the confusion between human rights and citizens" rights in the 1992 Constitution. A number of new rights, including the rights to life; the rights to live in a clean environment; the rights to conduct scientific research and the rights to access and enjoy culture values, have been supplemented in the 2013 Constitution, reflecting the progress of integration and development in Vietnam. The Constitution also introduces a new principle of mutual control among the three branches of government, based on the idea of direct democracy while continuing to give more rights to private enterprise.

In April 2016, the Vietnamese government approved the Socio-Economic Development Plan (SEDP) for the period 2016-2020. The plan highlights the importance of structural reforms, environmental sustainability, social equity and also the need for stabilizing macroeconomic. The plan also addresses some of the structural problems facing the economy by focusing on promoting skillsdevelopment for modern industry and innovation; improving market institutions, and further development of infrastructure.

\section{External Liberalization and Macroeconomics in Vietnam Since Its Economic Reform}

The comprehensive economic and political reforms - under the Doi Moi Policy have been the major catalyst of economic growth and development in Vietnam since 1986. During thirty years of the Doi Moi Policy, economic domestic reforms and an open-door policy toward international investment have brought about higher growth rates of GDP, a massive influx of FDI, an impressive industrial

\footnotetext{
40 "The Vietnam Stock Index or VN-Index is a capitalization-weighted index of all the companies listed on the Ho Chi Minh City Stock Exchange", https://www.bloomberg.com/quote/VNINDEX:IND.
} 
performance as well as a higher level of inequality in Vietnam. This section analyzes the evolution of economic growth; inflation, exchange rates and foreign exchange reserves; trade openness; foreign direct investment (FDI); industrial performance and income distribution as well as inequality during the six phases of the Doi Moi Policy.

\subsection{Economic Growth of Vietnam since its Economic Reform}

Since the launch of Doi Moi, Vietnam has transformed the nation from one of the poorest countries in the world to a middle-income country and from a closed centrally planned economy to a socialist market-oriented economy (Bhatt, 2013). The country has displayed high rates of economic growth as well as an impressive performance in financial integration and trade liberalization. After Doi Moi, Vietnam has also been reducing its poverty rate and stabilizing its macroeconomic variables and has become one of the fast-growing economies in the South East Asia with GDP of US\$202.62 billion and per capita GDP US\$2,115 in 2016. The GDP growth rate of Vietnam was 6.1 percent in 2016 while it was 3.2 percent, 1.7 percent and 4.3 percent in Thailand, Singapore and Malaysia respectively. In terms of current US dollars, GDP of Vietnam rose from $\$ 5$ billion in 1986 to a 1996 level of $\$ 25$ billion and about $\$ 202.62$ billion in 2016. There has also been a dramatic increase in GDP per capita which rose from $\$ 81$ in 1986 to a 1996 level of $\$ 276$ and $\$ 2,115$ in 2016.

Figure 1 presents the growth rate of GDP and GDP per capita of Vietnam since its Doi Moi. During the first phase of the Doi Moi Policy (1986-1993), the growth rate of GDP grew from 4 percent in 1985 to almost 8 percent in 1989 after the introduction of the first Law on Foreign Investment in 1987 and other reforms. However, the disintegration of the most important trading partners - the Soviet Union Bloc led to a decline in GDP growth rate to 5 percent in 1991. The collapse of the Soviet Union was the catalyst to more extensive reforms. The Corporate Law and Private Enterprise Law initiated in 1990 granted private enterprises which led to an increase by 17,400 start-up entrepreneurial enterprises in 1994. Finding new trading partners through an open-door policy was also the first priority of Vietnamese economy during 1991-1993. Since 1991, the government has also given private enterprises permission to directly export and import. Those policies resulted in an increase in 8.5 percent in GDP growth rate in 1993.

Figure 1: The Growth Rates of GDP and GDP Per Capita in Vietnam

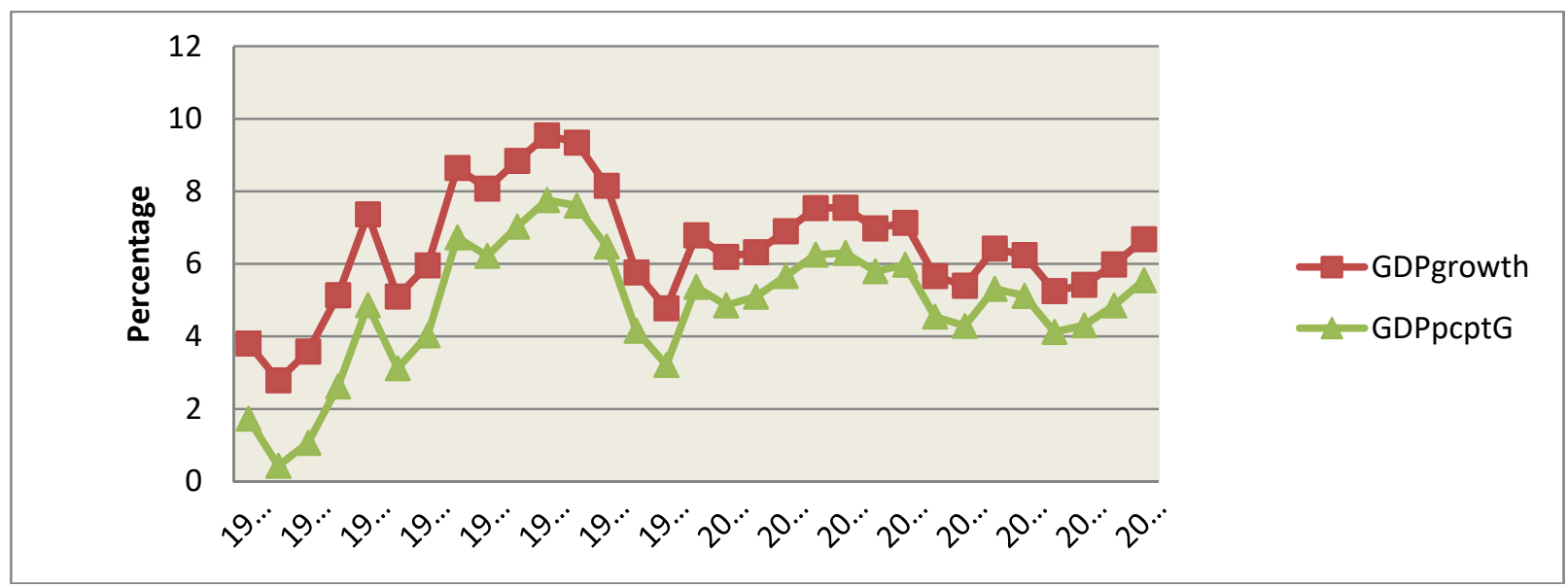

Source: Author's computation from UN dataset

We see remarkable growth rates of both GDP and GDP per capita in Vietnam during the second phase of the Doi Moi Policy (1994-1997), especially after 1995 when Vietnam gradually integrated to the world economy through various trade agreement (Nguyen et al, 2012).

The growth rate of GDP reached a peak of 9.8 percent in 1996, thanks to the comprehensive economic reforms in domestic in the second phase of the Doi Moi Policy. However, the growth rates of 
GDP and GDP per capita of Vietnam decreased to 4 and 3 percent respectively in 1999 due to the Asian financial crisis in 1997.

The fourth phase of the Doi Moi Policy (2001-2007) experienced more stable economic growth rates at around 7 percent but fell to 6 percent after the world financial crisis in 2008. The Vietnamese government has focused on stabilizing macroeconomic performance and controlling inflation through an economic stimulus package of VND 30,000 billion (about USD1.5 billion) in early 2013 which has restored the growth rate of both GDP and GDP per capita in the current phase.

In short, during thirty years (1986-2016) of the Doi Moi Policy, Vietnam has integrated her economy to the world and regional economic market and experienced a notable economic growth rate.

\subsection{Inflation, Exchange Rate and Foreign Reserves in Vietnam}

Table 2: Inflation, Exchange Rates and Foreign Exchange Reserves

\begin{tabular}{|c|c|c|c|}
\hline Year & Inflation $(\%)$ & $\begin{array}{c}\text { Exchange Rates } \\
\text { (VND/USD) }\end{array}$ & $\begin{array}{c}\text { Foreign Exchange Reserves } \\
\text { (\% Nominal GDP) }\end{array}$ \\
\hline 1995 & 5.67 & 11038.25 & 6.37 \\
1996 & 3.20 & 11032.58 & 7.11 \\
1997 & 7.26 & 11683.33 & 7.5 \\
1998 & 4.11 & 13268.00 & 8.01 \\
1999 & -1.71 & 13943.17 & 13 \\
2000 & -0.43 & 14167.75 & 12.11 \\
2001 & 3.83 & 14725.17 & 12.5 \\
2002 & 3.21 & 15279.50 & 13.23 \\
2003 & 7.75 & 15509.58 & 16.2 \\
2004 & 8.28 & 15746.00 & 15.9 \\
2005 & 7.38 & 15858.92 & 15.8 \\
2006 & 8.30 & 15994.25 & 20 \\
2007 & 23.11 & 16105.13 & 30.36 \\
2008 & 7.05 & 16302.25 & 25 \\
2009 & 8.86 & 17065.08 & 15 \\
2010 & 18.67 & 18612.92 & 11 \\
2011 & 9.09 & 20509.75 & 9.8 \\
2012 & 6.59 & 20828.00 & 17 \\
2013 & 4.08 & 20933.42 & 15 \\
2014 & 0.63 & 21148.00 & 17.62 \\
\hline
\end{tabular}

Source: The data of inflation and exchange rate is from UN datasets, the data of foreign exchange reserves is from CEIC (www.ceicdata.com/indicator/vietnam/foreign-exchange-reserves--of-gdp).

Table 2 presents the evolution of inflation, exchange rate and foreign exchange reserves in Vietnam during the period of 1995-2014. In Vietnam, the monetary policy, the exchange rate policy and foreign exchange reserves are administered and implemented by its central bank (the State Bank of Vietnam - SBV). The State Bank of Vietnam administers interest rate, exchange rates and control inflation and economic growth.

After thirty years of Doi Moi, the management of monetary policy has been more effective in easing and controlling inflation as well as stabilizing the macroeconomy. The Vietnamese government is pursuing a target of keeping inflation below 7 percent. However, the monetary policy is still not mature, and is sometimes conducted in a passive manner, reflecting the central banks limited capacity to control liquidity and inflation. For example, to deal with high inflation pressure, the State Bank of Vietnam pursued a tight monetary policy. Table II.2 shows mild inflation in Vietnam in the period of 1995 to the middle of 2007. During this period, the State Bank of Vietnam maintained a loose monetary policy and an expansive fiscal policy. The high inflation rate of 23 percent in late 2007 was eased by reducing required reserved ratio successively over a period of mid 2006-mid 2007. After the global financial crisis in 2008, the State Bank of Vietnam continues easing pressure of high inflation by loosening monetary policy. 
During the thirty years of Doi Moi, Vietnam's exchange rate regime has transformed from a multiple exchange rates to an announced fixed rate mechanism, then to the current system of a narrow fluctuation range around the official rate, which is itself set on a daily basis and reflects the interaction of foreign exchange market with other market forces (Nguyen and Nguyen, 2010). In Vietnamese foreign market, the US dollar has been considered as a key nominal anchor. Table II.2 presents the evolution of VND/USD exchange rate from 1995 to 2014. Since 1995, the VND/USD rate indicated major weakening of the VND against the USD. The State Bank of Vietnam is pursuing a policy of a controllable floating exchange rate regime to prevent increasing dollarization and the appreciation of Vietnamese Dong (VND) and also tightening the fluctuation range of USD/VND exchange rate.

Table 2 also shows the movement of foreign exchange reserves as percent of nominal GDP in Vietnam since 1995. Vietnam's foreign exchange reserves as share of GDP was reported at only 6.37 percent in 1995 but rose to 30.36 percent in 2007, reflecting the buoyant exports of the country. Due to the impact of the global financial crisis in 2008, the foreign exchange reserves in Vietnam declined to 9.8 percent in 2011 and has experienced an upward trend since 2012.

\subsection{Trade Performance of Vietnam Since its Reform}

Figure 2: Ratio of Trade in Vietnam
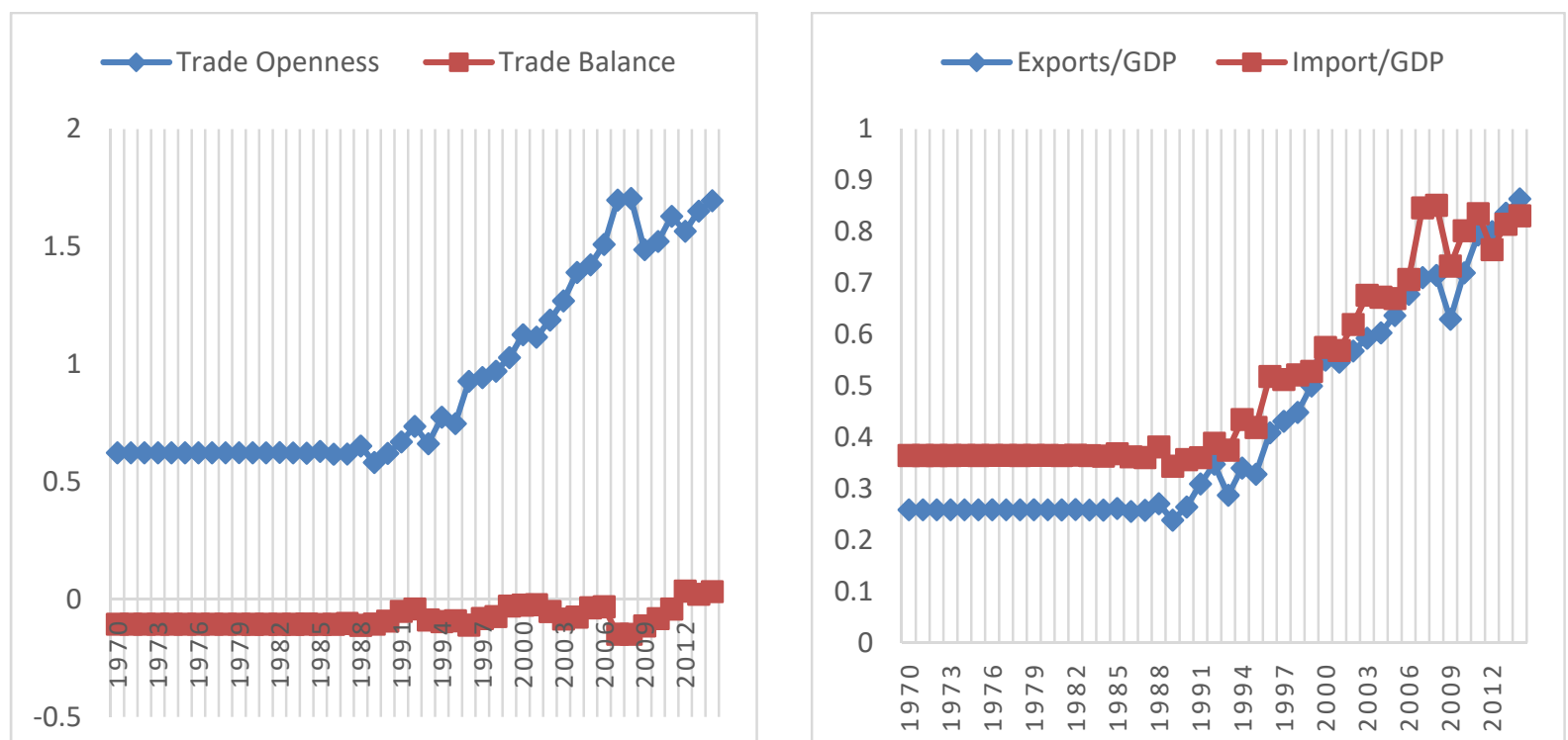

Source: Author's computation from different issues (1970-2014) of General Statistical Office, Statistical Yearbook of Vietnam and Vietnam Foreign Trade's dataset

Under the Doi Moi policy regime, Vietnam underwent remarkable transformation thanks to integration with the world trade market. The export-led growth strategy gave a boost to Vietnamese economy. The contribution of exports to GDP rose from 26 percent in 1970 to 40 percent in 1996 and 86 percent in 2014 (Figure 2). Trade openness measured by the sum of exports and imports as a percentage of GDP has increased from 62.3 percent in 1970 to 92.7 percent in 1996 and 169.5 percent in 2014.

Trade balance was always negative from 1970 to 2011 (see Figure 2). Since 2012, the trade balance has been positive thanks to the export-led policies through six phases of the Doi Moi Policy such as the private enterprises' permission to directly export and import in the first phase; the New Enterprise Law in 1999 and Decree 57 which gives more rights for export companies in the third phase; the permission to enterprises, individuals, cooperatives and foreign investors to export and import all permissible commodities by Decree 44/2001/ND-CP in 2001. 
Figure 3: Shares of Export by Region

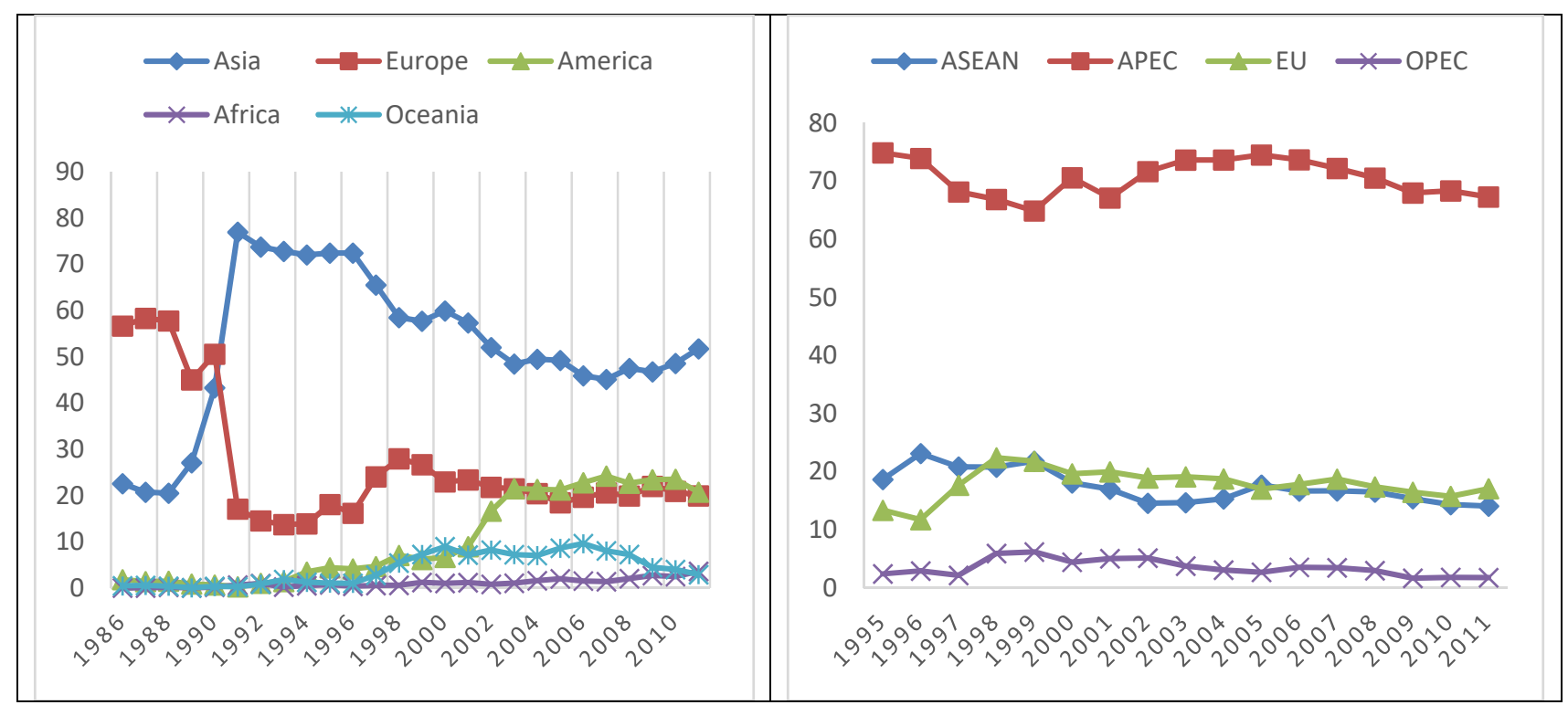

Source: Author's computation from various issues (1997-2012) of General Statistical Office, Statistical Yearbook of Vietnam

Before Doi Moi, Eastern Europe which provided 57 percent of Vietnam's imports used to be the main trading partner (Le, 2006). However, after Doi Moi and the disintegration of Soviet Union Bloc, Vietnam built trading relationship with other Asian countries. Figure 3 and Figure 4 describes the shares of Vietnamese export and import by regions (Asia, Europe, America, Africa and Oceania) and economic regions (ASEAN, APEC EU, OPEC) from 1997 to 2012. Among five regions, Asia has been the main export and import partners of Vietnam. Figure 3 shows a downward trend of Vietnamese export volumes to Europe. The export volumes to America has been increasing due to the normalization with the United States in 1995 and the bilateral trade agreement with the US in 2001. The share of export volumes to American region increased from 0.3 percent in 1986 to 7.8 percent in 2011. Vietnam used to import mostly from Europe because of the trading relationship with Western Europe. However, after the disintegration of the Soviet Union, import value from Europe decreased from 79 percent in 1986 to 10 percent in 2011. While, Vietnam import volume from Asia increased from 10 percent in 1986 to 78 percent in 2011. Among 4 economic regions, the main export and import partners of Vietnam are APEC, EU and ASEAN. Since the Doi Moi, APEC countries have always been the major export and import partners of Vietnam. The shares of export and import volumes to APEC were 74.8 percent and 79.6 percent in 1995 respectively. The share of export volume to APEC declined slightly to 67.3 percent in 2011, while the share of import volume from APEC increased slightly to 81 percent in 2011. 
Figure 4: Shares of Import by Region

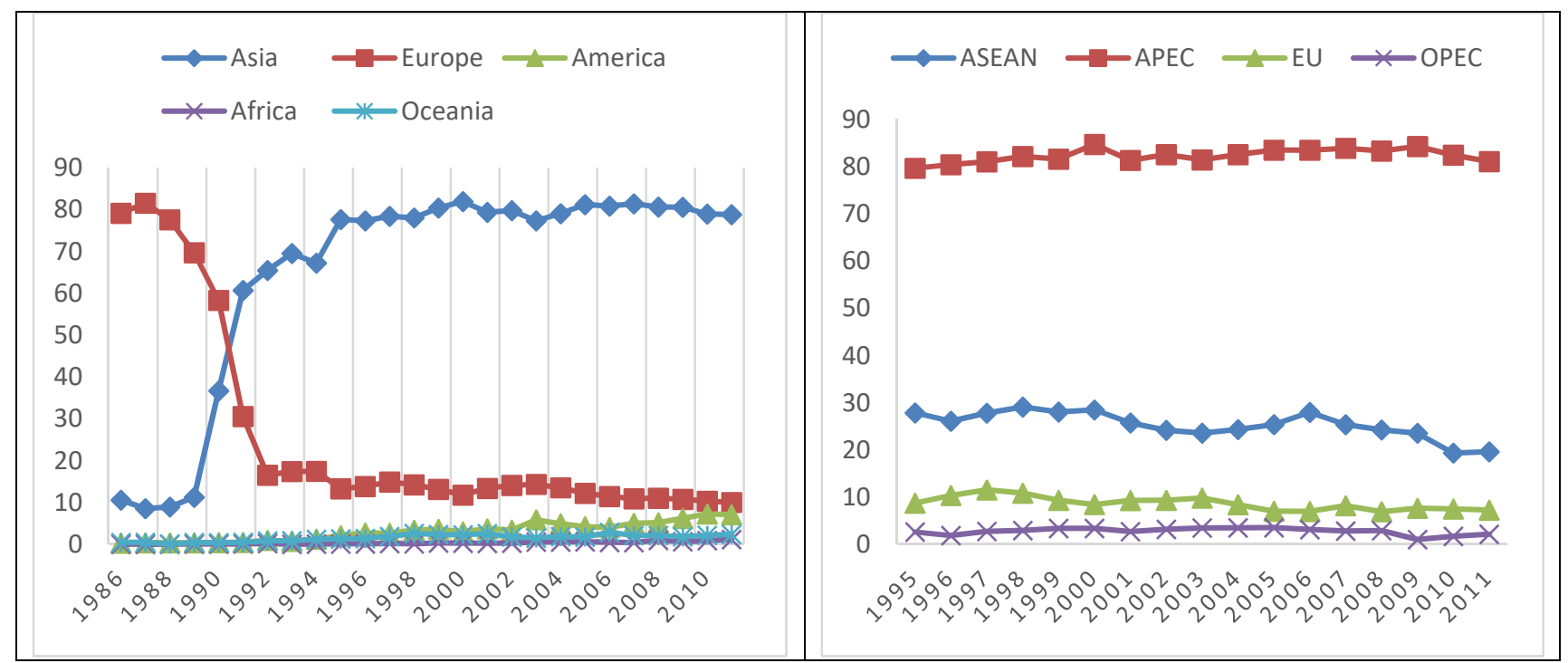

Source: Author's computation from various issues (1997-2012) of General Statistical Office, Statistical Yearbook of Vietnam

Figure 5: Export and Import Value by SITC Classification

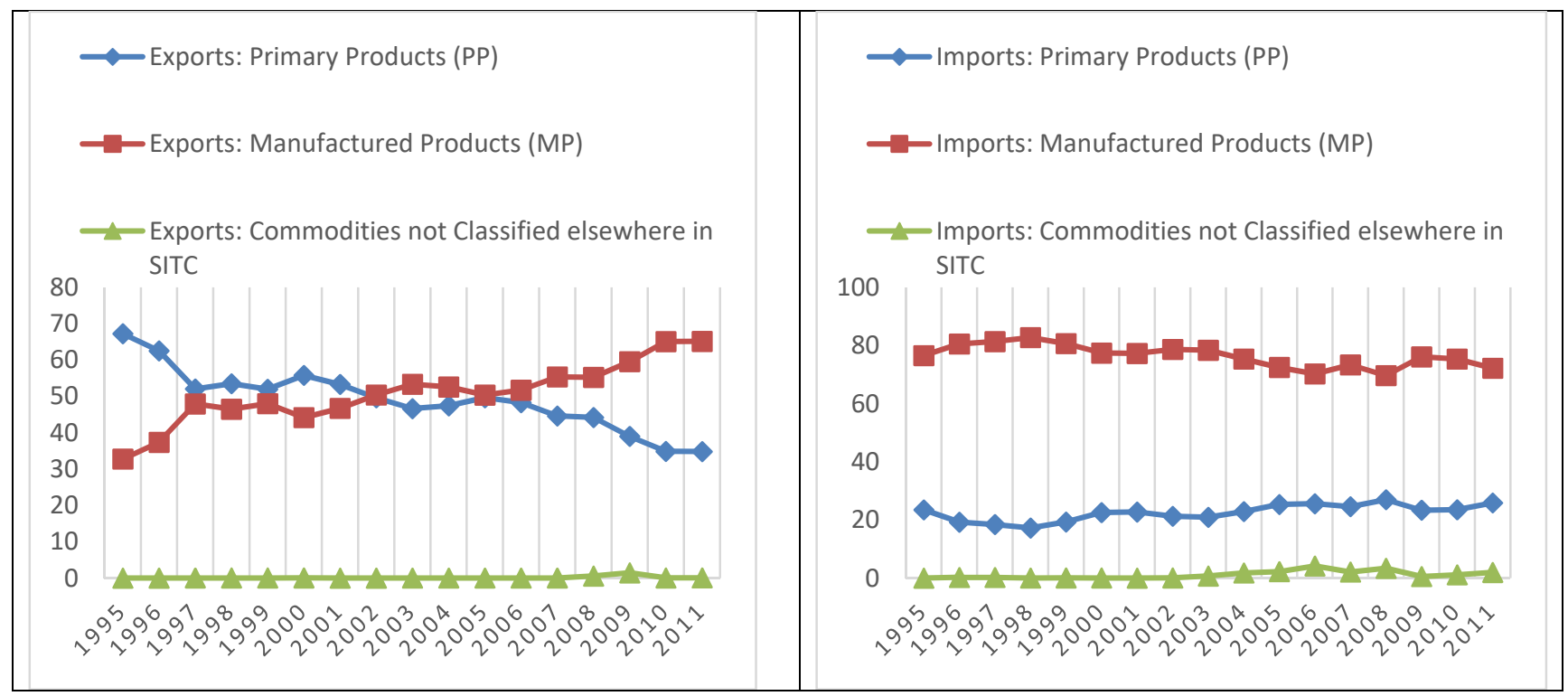

Source: Author's computation from different issues (1995-2011) of General Statistical Office, Statistical Yearbook of Vietnam. Unit: USD million.

The composition of Vietnamese exports had shifted during the period of 1995-2011. In the first few years of the launch of the Doi Moi, Vietnam only focused on the export of five main primary products: crude materials; food and live animal; beverage and tobacco; mineral fuels, lubricants and related material; animal and vegetable oils fat and wax. Later, Vietnamese export and import's structure have changed from mainly primary products to manufactured products. Figure 5 depicts the shares of export and import value of primary and manufactured products. In the early stages of the comprehensive reform and external liberalization, Vietnam mostly exported primary products and imported manufactured products. The share of primary product' export value decreased from 67 percent in 1995 to 34.8 percent in 2011, while the share of the manufactured product' export value increased from 32.7 percent in 1995 to 65.1 percent in 2011. In contrast, Vietnam mostly imports 
manufactured product, which share accounts for 72 percent in 2011, while the share of primary product' import value was 25.8 percent in the same year.

All in all, Vietnam has experienced substantial increase in international trade. During the period of 1970-2014, trade openness of Vietnam (measure by the sum of exports and imports as a percent of GDP) rose from 62 percent in 1970 to 169 percent in 2014 (Figure 4).

\subsection{The Trend of FDI in Vietnam Since its Reform}

Vietnam has exhibited a substantial increase in FDI inflows since the approval of the Law on Foreign Investment in 1987 (which was amended in 1992, 1996, 2000, 2003 and 2013). Also, in November 2005, the Unified Enterprise Law was passed and followed by the Unified Law on Investment in 2006, both laws supported foreign companies seeking to invest into Vietnam. These laws have had a positive impact on FDI inflows.

Figure 6: FDI Inflows in Vietnam from 1988 to 2013

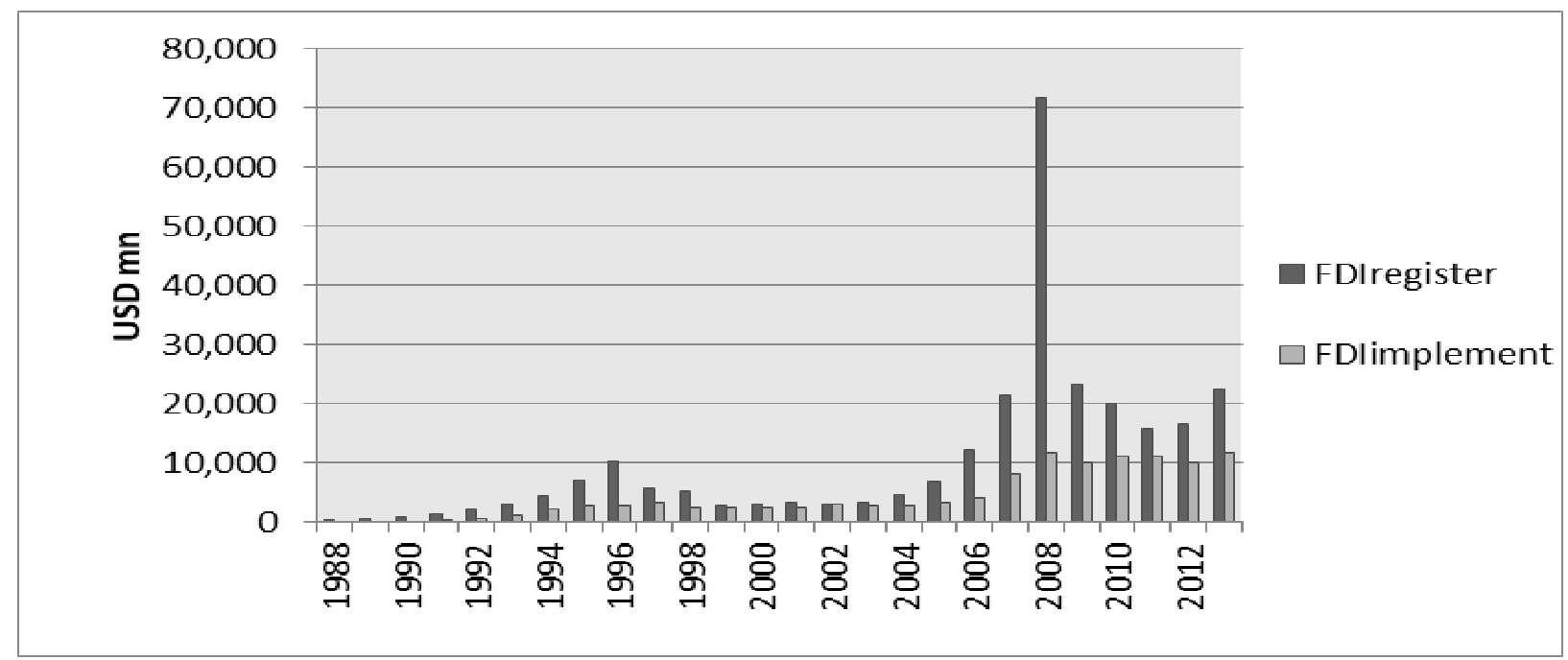

Source: Author's computation from various issues (1988-2013) of General Statistical Office, Statistical Yearbook of Vietnam

Figure 6 presents the trend of FDI in Vietnam in the period of 1988-2013 (both registered and implemented $\mathrm{FDI}^{41}$ ). The figure reflects the impact of Vietnamese reforms with new laws, which supported foreign investors and also the effects of trade liberalization through bilateral and multinational agreements. Registered FDI which represent 'potential FDI flows should be distinguished from implemented FDI which is the actual inflow. The registered FDI inflows rose nearly 30 times between 1988-1996. Registered FDI decreased substantially in the year following the Asian financial crisis but resumed the upward trend after 2002 and reached the peak in 2008 thank to the US-Vietnam Bilateral Trade Agreement in 2000 and the notable reform of FDI-related policy in late 2005. After the global financial crisis in 2008, the registered FDI inflows in Vietnam have been reduced by almost 75 percent in 2012 and resumed the upward trend since 2013. During the second phase of the Doi Moi Policy (1991-1997), the implemented FDI also increased nearly 10 times between 1991-1997. After the Asian financial crisis in 1997 and the global financial crisis in 2008, the implemented FDI inflows decreased in 1998 and in 2011, however it resumed the upward trend since 2012 following those tight policies of Communist Party of Vietnam to control inflation and stabilize the macroeconomy.

\footnotetext{
${ }^{41}$ Registered FDI is the amount of FDI registered in the contract between foreign companies and Vietnamese government; implemented FDI is the real amount of FDI invested in Vietnam by foreign companies.
} 
Table 2: $\quad$ Sectoral Composition of FDI Inflows by Sectors from 2010-2013

\begin{tabular}{|l|c|c|c|c|}
\hline \multicolumn{1}{|c|}{ Year } & $\mathbf{2 0 1 0}$ & $\mathbf{2 0 1 1}$ & $\mathbf{2 0 1 2}$ & $\mathbf{2 0 1 3}$ \\
\hline Agriculture, Forestry \& Fishery & 0.18 & 0.91 & 0.61 & 0.44 \\
Mining \& Quarrying & 0.00 & 0.00 & 0.00 & 0.00 \\
Manufacturing & $\mathbf{3 0 . 0 7}$ & $\mathbf{4 9 . 9 3}$ & $\mathbf{7 1 . 5 8}$ & $\mathbf{7 6 . 6 9}$ \\
Electricity, Gas, Air Con Supply & $\mathbf{1 4 . 8 5}$ & $\mathbf{1 6 . 2 1}$ & $\mathbf{0 . 5 9}$ & $\mathbf{9 . 1 1}$ \\
Water Supply, Sewerage, Remediation & 0.05 & 2.07 & 0.00 & 0.23 \\
Construction & $\mathbf{9 . 1 3}$ & $\mathbf{8 . 3 1}$ & $\mathbf{2 . 1 2}$ & $\mathbf{0 . 9 9}$ \\
Wholesale, Retail Trade, Motor Repair & 2.32 & 3.20 & 4.73 & 2.81 \\
Transportation, Storage & 4.43 & 0.48 & 1.39 & 0.30 \\
Accommodation, Food Service & 1.59 & 3.06 & 0.66 & 1.11 \\
Information, Communication & 0.54 & 5.75 & 2.55 & 0.39 \\
Financial, Banking, Insurance & $\mathbf{0 . 3 0}$ & $\mathbf{0 . 0 0}$ & $\mathbf{0 . 0 0}$ & $\mathbf{0 . 0 0}$ \\
Real Estate Activities & $\mathbf{3 4 . 3 4}$ & $\mathbf{5 . 5 8}$ & $\mathbf{1 2 . 1 1}$ & $\mathbf{4 . 2 6}$ \\
Professional, Scientific, Tech & 0.36 & 1.70 & 0.60 & 1.96 \\
Administration, Support Service & 0.02 & 0.03 & 0.03 & 0.04 \\
Education, Training & 0.38 & 0.07 & 0.64 & 0.57 \\
Human Health, Social Work & 1.03 & 0.57 & 0.86 & 0.40 \\
Arts, Entertainment, Recreation & 0.31 & 0.98 & 0.37 & 0.23 \\
Other Activities & 0.08 & 0.51 & 0.13 & 0.07 \\
\hline
\end{tabular}

Source: Author's computation from various issues (2010-2013) of General Statistical Office, Statistical Yearbook of Vietnam and GSO's website. Unit: Percent of total FDI capital

Table 3 presents share of FDI in Vietnam by sector from 2010 to 2013. FDI has flowed into almost all sectors in Vietnam. However, as shown in the table, the majority of FDI inflows in Vietnam were into manufacturing and real estate activities. The share of FDI inflows into manufacturing rose from 30.07 percent in 2010 to 76.69 percent in 2013 while the share of FDI inflows into real estate activities declined dramatically from 34.34 percent in 2010 to 4.26 percent in 2013 due to the effect of the global financial crisis in 2008 and the bubble and boom of property market in 2011.

Table 3: Top 21 Countries of Origin of FDI into Vietnam in 2015

\begin{tabular}{|c|l|c|c|}
\hline No & Country of Origin & Number of projects & Percent of total FDI capital \\
\hline 1 & Korea & 736 & 28.9 \\
2 & Malaysia & 29 & 10.2 \\
3 & Singapore & 138 & 8.6 \\
4 & Japan & 319 & 7.4 \\
5 & Taiwan & 115 & 6.1 \\
6 & Samoa & 24 & 5.3 \\
7 & United Kingdom & 32 & 5.3 \\
8 & British Virgin Islands & 56 & 5.1 \\
9 & Hong Kong SAR (China) & 96 & 4.7 \\
10 & China. PR & 175 & 3.1 \\
11 & Turkey & 2 & 2.7 \\
12 & Netherlands & 26 & 1.8 \\
13 & Thailand & 35 & 1.4 \\
14 & Seychelles & 19 & 1.3 \\
15 & Cayman Islands & 6 & 1.1 \\
16 & United States & 37 & 0.9 \\
17 & Australia & 20 & 0.83 \\
18 & Brunei & 4 & 0.81 \\
19 & British West Indies & 24 & 0.6 \\
20 & India & 9 & 0.5 \\
21 & Switzerland & 0.4 \\
\hline
\end{tabular}

Source: GSO website: https://www.gso.gov.vn/default_en.aspx?tabid=776, download date 11/18/2016 
Most of FDI inflows to Vietnam have come from Asian countries and has been directed toward "oil and gas production, import-substituting industries, and export sectors such as garments and footwear" from 1990 to 2000 (Le, 2006) and toward manufacturing, real estates and construction since 2001. Table 4 presents the distribution of FDI by country of origin in 2015. There are 21 countries which invested more than US\$100 million. Korea invested in 736 projects worth about US\$6,983.2 million and accounted for 29 percent of total FDI capital, was the biggest foreign investor in Vietnam in 2015 followed by Malaysia with US\$2,478 million and Singapore with US\$2,082.5 million. The other top five foreign investors in Vietnam are Japan with US\$1,803.4 million and Taiwan with US\$1,468.2 million. Geographical proximity and propinquity are the main reasons why most of FDI inflows into Vietnam originated from Asian countries.

Figure 7: Investment by Ownership Sectors in Vietnam

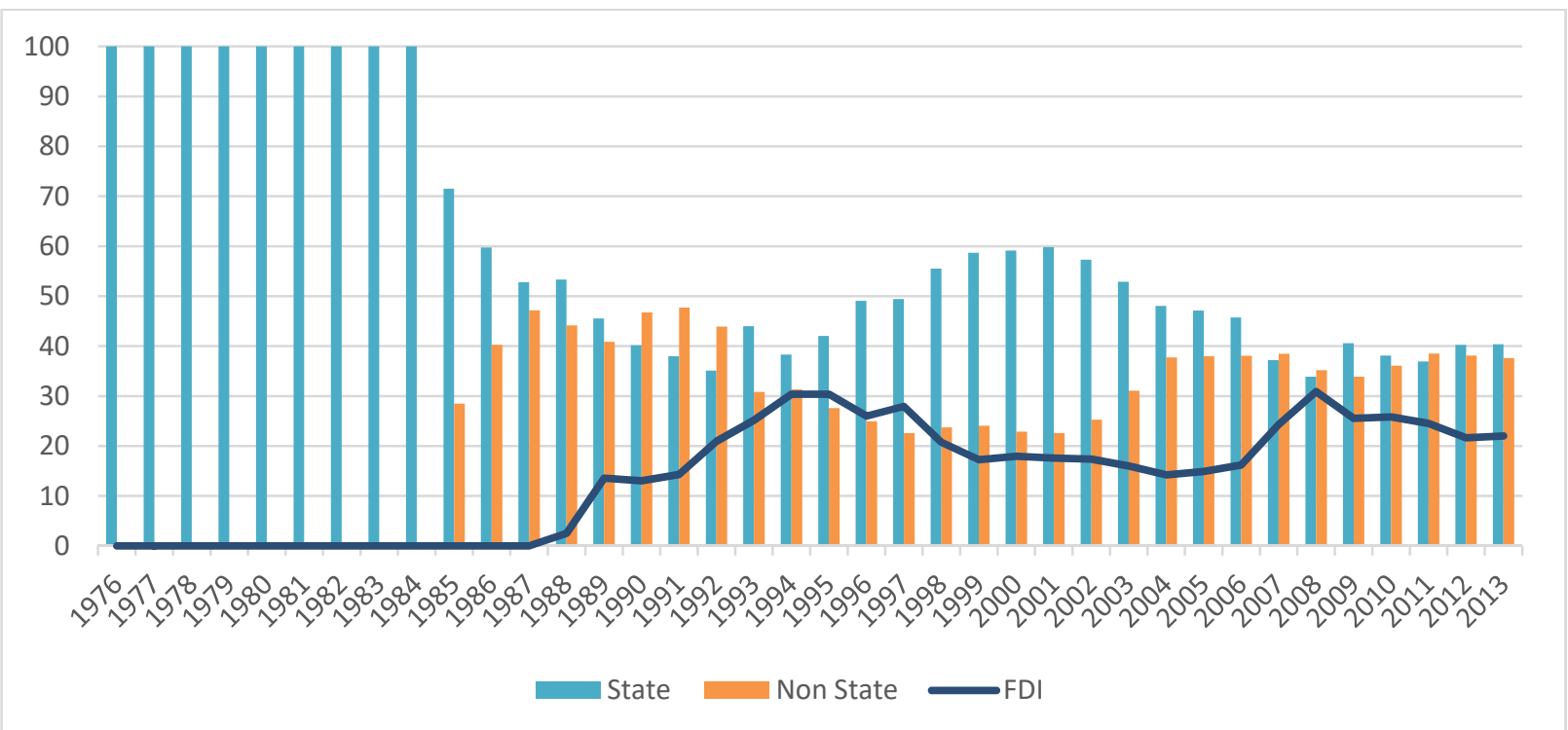

Source: Author's computation from various issues (1988-2013) of General Statistical Office, Statistical Yearbook of Vietnam and GSO's website. Unit: percent of total investment.

Thus, FDI inflows have played an important role in Vietnamese economy in general and in total investment of the whole country. Figure 7 depicts the shares of investment by ownership in Vietnam from 1976 to 2013, of which the investments of state government are majority. Before Doi Moi, the share of state investment was 100 percent. Private sectors launched investments in 1986, while foreign investors began to enter in 1988. The share of FDI inflows in the total investment of Vietnam have been increasing during the period 1988-2013. Especially, FDI inflows accounted for 30 percent of the total investment in 1995, 1996 and over 31 percent in 2008. There has been a downward trend in the share of government investment relative to private and FDI sectors since 1995 reflecting the transition from centralized to a market-oriented economy and from isolation to international integration.

\subsection{Industrial Performance of Vietnam Since 1976}

During trade liberalization and the comprehensive economic reforms, Vietnam has experienced an impressive industrial performance. The growth rate of gross industrial output (GIO) fluctuated in the period of 1976 - 1994, then grew at a more stable rate of around 15 percent till 2007, and then declined after the global financial crisis of 2008. Before the Doi Moi Policy, the trade embargo from advanced capitalist countries made Vietnam into an effectively closed economy and domestic industries did not have to compete with foreign competitors and imports. After 1989, because of the collapse of Soviet bloc and the open-door economic policy which subjected domestic industry to new global competition, there was a sharp decline in GIO growth rate in 1990. However, during the period 1994-2007, Vietnam 
had enjoyed a stable and higher rate of GIO through 2007 until the global financial crisis of 2008 led to a decline of 6.3 percent in GIO growth rate in 2012 (Figure 8).

Figure 8: Gross Industrial Output Growth Rate of Vietnam

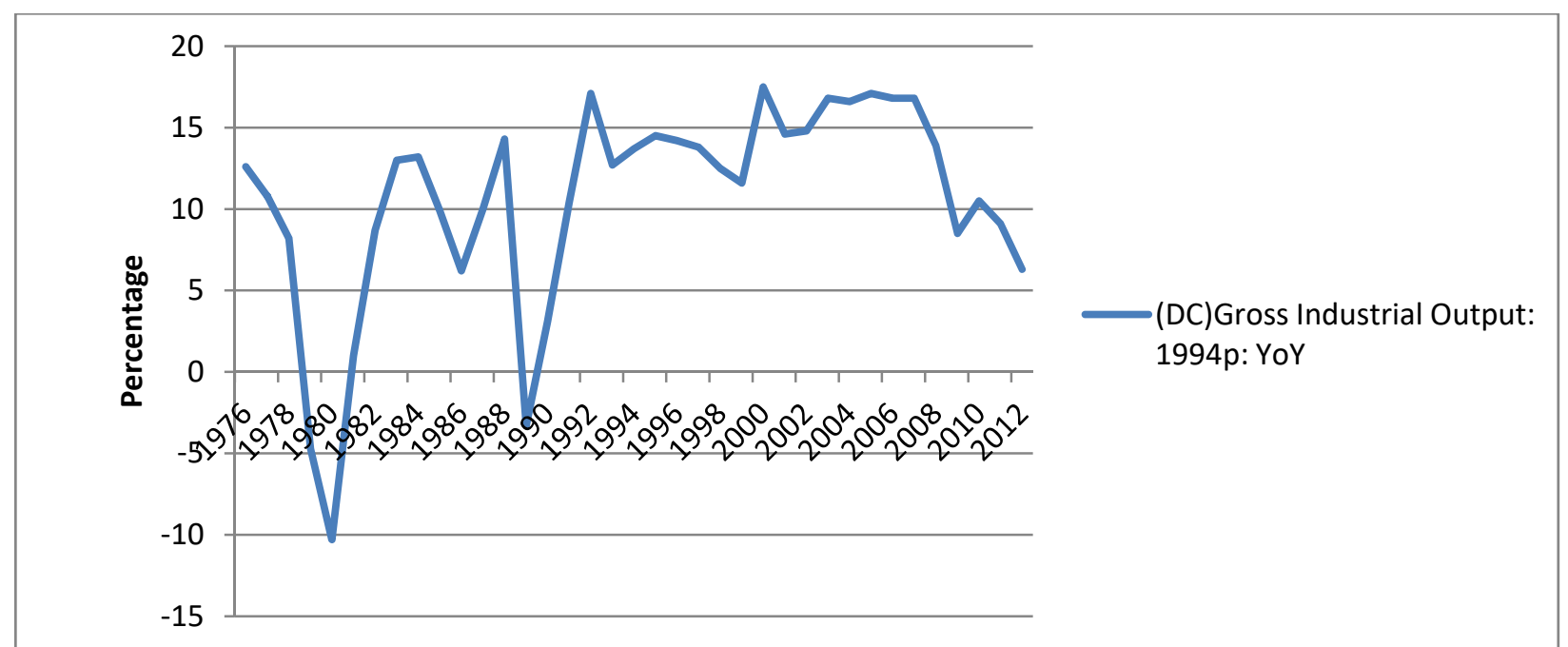

Source: The growth rates of Gross Industrial Output were calculated by General Statistical Office. The data was collected from different issues (1976-2012), Statistical Yearbook of Vietnam.

Figure 9 presents the growth rate of gross industrial output calculated by General Statistical Office (GSO) in the period of 1976-2012 and the gross industrial output from 1996 to 2013 by ownership: state, non-state and foreign investment sector. As shown in the figure, from 1976 to 1986, the gross industrial output of state-owned companies grew fast in 1976 after the country's reunification then declined significantly in 1982. After 1986, growth rate of GIO in the state-owned sector rose steadily until 1995. The growth rate of GIO of state-owned sections decreased while the GIO growth rates of non-state owned and foreign investment sectors increased significantly and reached their peak in 2005 with 25 percent and 21 percent growth respectively. However, after the global financial crisis in 2008, the GIO growth rate of non-state-owned companies was only 0.4 percent in 2012 while they are 6.3 percent and 6.5 percent for state owned and foreign investment sectors.

Figure 9: Gross Industrial Output and GIO Growth Rate by Ownership Sectors
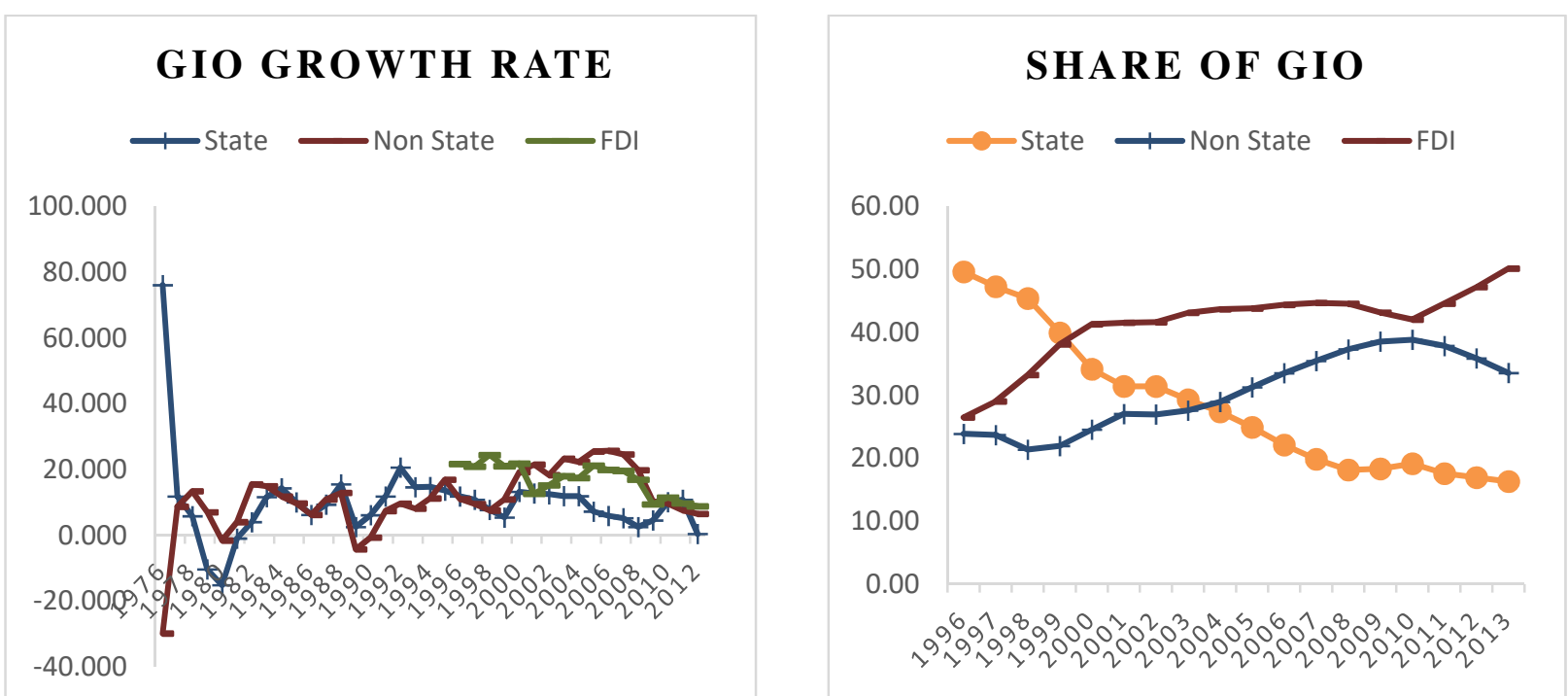

Source: Author's computation from various issues of Statistical Yearbook of Vietnam (General Statistical Office) from 1976 to 2012 for GIO growth rate and from 1996 to 2013 for the share of GIO. 
The gross industrial output of Vietnam has been increasing significantly since 1996 for all sectors by ownership. A rise in the shares of non-state and foreign investment sector in the gross industrial output of Vietnam during the period 1996-2013 is observed. In 1996, the share of GIO in the state-owned sectors was about 50 percent while it was only 24 percent for non-state owned and 26 percent foreign investment sectors. Yet, in 2013, the shares of GIO in FDI sectors rose to about 50 percent, while the share of state-owned sector declined to about 16 percent. This is a reversal of the relative positions of the two sectors and suggests that the foreign investment sectors have grown in importance in Vietnam's industrial sector.

\subsection{Income Distribution, Inequality and Poverty in Vietnam Since Doi Moi}

The Doi Moi reforms and liberalization have brought prosperity to Vietnamese economy and also improved Vietnamese people's living standards in both urban and rural areas. After thirty years of the Doi Moi Policy, income distribution in Vietnam has experienced impressive changes. For example, during the period of 2005-2015, per capita GDP grew annually at rate of 5 percent while the expenditure per month of Vietnamese family has increased by from VND 792 (US\$40) in 2008 to VND 1,888 (US\$80) in 2014.

However, there is a growing urban-rural gap in average income per capita in Vietnam, which can be explained by the widening labor productivity growth gap between the primary (agriculture, forestry and fishing), manufacturing, construction and service sectors. The monthly average income per capita in both urban and rural areas has grown which were VND 517 thousand (US\$30) and VND 225 thousand (US\$15) in 1999, respectively, while it was VND 3,964 thousand (about US\$200) and VND 2,038 thousand (US\$100) in 2014, respectively (see Table 5 and Table A.1 in appendix.

Table 4: $\quad$ Monthly Average Income Per Capita and GINI Index

\begin{tabular}{|c|c|c|c|c|c|c|}
\hline \multirow{2}{*}{ Year } & \multicolumn{2}{|c|}{ Whole Country } & \multicolumn{2}{c|}{ Urban } & \multicolumn{2}{c|}{ Rural } \\
\cline { 2 - 7 } & Per Capita Income & GINI & Per Capita Income & GINI & Per Capita Income & GINI \\
\hline 1999 & 295 & n.a & 517 & n.a & 225 & n.a \\
2002 & 356 & 0.42 & 622 & 0.41 & 275 & 0.36 \\
2004 & 484 & 0.42 & 815 & 0.41 & 378 & 0.37 \\
2006 & 636 & 0.424 & 1058 & 0.393 & 506 & 0.378 \\
2008 & 995 & 0.434 & 1605 & 0.404 & 762 & 0.385 \\
2010 & 1387 & 0.433 & 2130 & 0.402 & 1070 & 0.395 \\
2012 & 2000 & 0.424 & 2989 & 0.385 & 1579 & 0.399 \\
2014 & 2637 & 0.43 & 3964 & 0.397 & 2038 & 0.398 \\
\hline
\end{tabular}

Source: GSO, Unit: Thousand Vietnamese Dong at current prices

Vietnamese inequality (Gini coefficient) has continually increased since the Doi Moi and opening-up policies. For example, the Gini coefficient of the whole country increased from 0.42 in 2002 to 0.43 in 2014. However, the Gini coefficient of urban area has declined from 0.41 in 2002 to 0.397 in 2014, while the Gini coefficient of rural area has increased from 0.36 to 0.398 (see Table 4). Thus, while inequality in rural Vietnam has declined, inequality is seen some increase in urban Vietnam.

The adoption and implementation of the Doi Moi Policy has brought spectacular changes in the socio-economic-political situation of the country in the past 30 years (1986-2016). Poverty reduction is one of the most remarkable achievement of Doi Moi Policy. Table 6 exhibits some key social indices with some improvements evident in all social indicators such as HDI. 
Table 5: $\quad$ Some Key Social Indicators

\begin{tabular}{|l|c|c|c|c|c|c|c|}
\hline \multicolumn{1}{|c|}{ Year } & $\mathbf{2 0 0 6}$ & $\mathbf{2 0 0 8}$ & $\mathbf{2 0 1 0}$ & $\mathbf{2 0 1 2}$ & $\mathbf{2 0 1 3}$ & $\mathbf{2 0 1 4}$ & $\mathbf{2 0 1 5}$ \\
\hline Human Development Index (HDI) & n.a. & n.a. & 0.6 & 0.7 & 0.7 & 0.7 & 0.7 \\
Patient bed per 10000 inhabitants (Bed) & n.a. & n.a. & 22 & 24.9 & 25 & 26.3 & 27.1 \\
Doctor per 10000 inhabitants (Pers.) & n.a. & n.a. & 7.1 & 7.3 & 7.6 & 7.9 & 8 \\
Monthly average income per capita at current prices (Thous. VND) & 636 & 995 & 1387 & 2000 & n.a. & 2637 & n.a. \\
Monthly average expenditure per capita at current prices (Thous. & 511 & 792 & 1211 & 1603 & n.a. & 1888 & n.a. \\
VND) & 89.1 & 92.1 & 90.5 & 91 & n.a. & 93 & n.a. \\
Percentage of household having hygienic water (\%) & 59.1 & 65 & 75.7 & 77.4 & n.a. & 83.6 & n.a. \\
Percentage of household using toilet (\%) & 96 & 97.6 & 97.2 & 97.6 & n.a. & 98.3 & n.a. \\
Percentage of household using electricity (\%) & 99 & 99 & 98.4 & 99.4 & n.a. & 99.7 & n.a. \\
Percentage of households having durable goods (\%) & 14.7 & 16.3 & 17.9 & 19.4 & n.a. & 21.4 & n.a. \\
Average dwelling area per capita (m2) & & &
\end{tabular}

Source: Author's computation from various issues of Statistical Yearbook of Vietnam

Table 6: General Poverty Rate by Residence in Vietnam

\begin{tabular}{|l|c|c|c|c|c|c|c|c|c|c|c|}
\hline \multicolumn{1}{|c|}{ Year } & $\mathbf{1 9 9 8}$ & $\mathbf{2 0 0 2}$ & $\mathbf{2 0 0 4}$ & $\mathbf{2 0 0 6}$ & $\mathbf{2 0 0 8}$ & $\mathbf{2 0 1 0}$ & $\mathbf{2 0 1 1}$ & $\mathbf{2 0 1 2}$ & $\mathbf{2 0 1 3}$ & $\mathbf{2 0 1 4}$ & $\mathbf{2 0 1 5}$ \\
\hline Whole Country & 37.4 & 28.9 & 18.1 & 15.5 & 13.4 & 14.2 & 12.6 & 11.1 & 9.8 & 8.4 & 7 \\
Urban & 9 & 6.6 & 8.6 & 7.7 & 6.7 & 6.9 & 5.1 & 4.3 & 3.7 & 3 & 2.5 \\
Rural & 44.9 & 35.6 & 21.2 & 18 & 16.1 & 17.4 & 15.9 & 14.1 & 12.7 & 10.8 & 9.2 \\
\hline
\end{tabular}

Source: GSO website

During the period of 1998-2015, the poverty rate has decreased from 37.4 percent in 1998 to 7 percent in 2015. However, Doi Moi Policy has also brought growing inequality between the rich and the poor, between the rural and urban population and between ethnic minorities and the majority of the population. Table 7 presents the general poverty rate by residence and region in Vietnam which shows a big difference in poverty rate between the urban and rural area. In 1998, the rate was 9 percent in urban area while it was much higher of 44.9 percent in rural area. The gap was narrowed by 2015 with the poverty rate falling to 2.5 percent and 9.2 percent respectively. Moreover, according to Vietnam Living Standard Survey (VLSS) in 2000, per capita income in the richest region is 4.5 times higher than that of the poorest (Tran \& To, 2000). There is also greater disparity between the access of the rich and the poor to basic social services especially in health care and education. For example, illiteracy rates and the quality of education are very high in a poor region based on VLSS in 1992 and 1998. The disparity in access to health care services between the rich and the poor has also increased.

\section{Decomposition of Shifts in Effective Demand 4.1. The Decomposition Technique of Effective Demand}

Thus, Vietnam has exhibited notable economic growth and development during the past thirty years thanks to the comprehensive reforms with an open-door policy toward international trade and investment. This section will examine the role of external liberalization as a determinant of macroeconomic performance in Vietnam during this period. Following Berg and Taylor (2000), I decompose aggregate demand with a two-step process. We distinguish the foreign sector from the domestic sector in the first step and decompose the domestic demand into government and private sectors in the second step.

Effective demand is the outcome of the balance between demand "injections" and "leakages" (Berg and Taylor, 2000). The injections are private investment in fixed capital and inventories, government spending and exports, while leakages are private saving, taxes and imports.

The total value of supply (X) is determined by injections and leakages. The injections of public sector, private sector and external sector are total government spending (G), private investment (Ip) and exports (E), respectively. The corresponding leakages of the three sectors are taxation (tX), savings $(\mathrm{sX})$ and imports $(\mathrm{mX})$. 
Then the decomposition of the sources of effective demand is the following equation:

$(I-s X)+(G-t X)+(E-m X)=0$

Where: $X$ is the total supply; $I$ is investment and $s$ is saving rate; $G$ is government spending, $t$ is tax rate and; $E$ is export, $m$ is the propensity to import.

\subsection{Analyzing the Sources of Effective Demand in Vietnam}

In the gross domestic product by expenditure approach, Vietnamese's GDP is divided into three parts: consumption, investment and exports. Table 8 presents the average growth rate of consumption, investment, and exports and imports of goods and services in real term since 1990, while the decomposition of foreign and domestic sectors is presented in Table 9. As shown in Table 8, the second phase of the Doi Moi Policy (1994-1997) experienced the highest growth rates of GDP, consumption spending, aggregate investment and export growth. For example, aggregate investment spending grew to its peak in 1995, increasing by nearly 15 percent, GDP growth rate reached to its peak of 9.5 percent in the same year, suggesting that the implementation phase of the Doi Moi Policy brought better macroeconomic performance in Vietnam. The growth rate of exports and imports also reflect impact of the Doi Moi Policy. The export-led strategy adopted under the Doi Moi Policy lead to high growth rates of exports, with a peak of 29.8 percent in 1991. Vietnamese exports continued to grow at high rates through the period of 1994-2008. However, the growth rate of export fell by 5 percent in 2009 following the global financial crisis in 2008. Following the comprehensive policies to control inflation and stabilize domestic macroeconomic as well as comprehensive monetary policies to devalue currency and the stimulate package of USD1.5 billion in 2013, exports grew at higher rates of 15 percent and 17 percent in 2012 and 2013.

Table 7: GDP Expenditure Components: Average Annual Growth Rate

\begin{tabular}{|c|c|c|c|c|c|c|c|}
\hline Year & GDP $(\%)$ & $\begin{array}{c}\text { Consumption } \\
(\%)\end{array}$ & $\begin{array}{c}\text { Private } \\
\text { Consumption } \\
(\%) \\
\end{array}$ & $\begin{array}{c}\text { Government } \\
\text { Consumption } \\
(\%)\end{array}$ & $\begin{array}{c}\text { Fixed Capital } \\
\text { Formation }(\%)\end{array}$ & $\begin{array}{c}\text { Exports of } \\
\text { Goods and } \\
\text { Services (\%) }\end{array}$ & $\begin{array}{c}\text { Imports of } \\
\text { Goods and } \\
\text { Services }(\%)\end{array}$ \\
\hline 1990 & 5.10 & 3.54 & n.a. & n.a. & n.a. & 12.93 & -4.50 \\
\hline 1991 & 5.96 & 0.08 & n.a. & n.a. & n.a. & 29.86 & -6.36 \\
\hline 1992 & 8.64 & 3.87 & n.a. & n.a. & n.a. & 24.67 & 18.79 \\
\hline 1993 & 8.07 & 10.38 & n.a. & n.a. & n.a. & 9.13 & 41.82 \\
\hline 1994 & 8.83 & 7.43 & n.a. & n.a. & n.a. & 16.00 & 31.47 \\
\hline 1995 & 9.54 & 7.41 & 7.21 & 8.40 & 14.75 & 20.00 & 16.27 \\
\hline 1996 & 9.34 & 8.14 & 9.09 & 7.43 & 14.01 & 24.00 & 21.30 \\
\hline 1997 & 8.10 & 6.01 & 5.91 & 4.00 & 10.16 & 16.00 & 9.65 \\
\hline 1998 & 5.76 & 4.29 & 4.47 & 3.22 & 12.41 & 19.00 & 18.39 \\
\hline 1999 & 4.77 & 2.19 & 2.60 & -5.70 & 1.58 & 23.00 & 12.56 \\
\hline 2000 & 6.78 & 3.92 & 3.08 & 5.01 & 10.18 & 21.10 & 16.61 \\
\hline 2001 & 6.19 & 4.37 & 4.47 & 6.60 & 10.72 & 17.18 & 16.44 \\
\hline 2002 & 6.32 & 7.41 & 7.63 & 5.38 & 12.86 & 10.37 & 15.79 \\
\hline 2003 & 6.89 & 7.22 & 8.01 & 7.19 & 11.90 & 19.95 & 22.72 \\
\hline 2004 & 7.53 & 4.49 & 7.09 & 7.77 & 10.44 & 25.62 & 21.94 \\
\hline 2005 & 7.54 & 3.39 & 7.26 & 8.20 & 9.75 & 17.78 & 14.18 \\
\hline 2006 & 6.97 & 5.77 & 7.47 & 8.50 & 9.90 & 11.20 & 11.99 \\
\hline 2007 & 7.12 & 13.12 & 9.78 & 8.90 & 24.16 & 12.50 & 26.93 \\
\hline 2008 & 5.66 & 7.80 & 7.67 & 7.52 & 3.84 & 13.70 & 15.01 \\
\hline 2009 & 5.39 & 2.37 & 2.25 & 7.60 & 8.73 & -5.09 & -6.82 \\
\hline 2010 & 6.42 & 4.55 & 8.19 & 12.28 & 10.89 & 8.45 & 8.22 \\
\hline 2011 & 6.24 & 5.79 & 4.10 & 7.12 & -7.81 & 10.78 & 4.10 \\
\hline 2012 & 5.25 & -0.20 & 4.88 & 7.19 & 1.87 & 15.71 & 9.09 \\
\hline 2013 & 5.42 & 5.19 & 5.18 & 7.26 & 5.30 & 17.37 & 17.34 \\
\hline 2014 & 5.98 & 6.24 & 6.12 & 7.00 & 9.27 & 11.56 & 12.80 \\
\hline 2015 & 6.68 & 13.29 & 6.33 & 9.96 & 9.37 & 12.64 & 18.12 \\
\hline
\end{tabular}

Source: Author's calculation from WDI (2016) 
Table 8: Decomposition of Foreign and Domestic Sectors

\begin{tabular}{|c|c|c|c|c|c|}
\hline Year & $\mathrm{X}=\mathrm{GDP}+\mathrm{M}$ & $\mathrm{m}=\mathrm{M} / \mathrm{X}$ & $\mathrm{s}=(\mathrm{GDP}-\mathrm{C}) / \mathrm{X}$ & $\mathbf{I} / \mathbf{s}$ & E/m \\
\hline 1994 & 23,364 & 0.30 & 0.11 & 35,372 & 18,285 \\
\hline 1995 & 29,426 & 0.30 & 0.13 & 41,446 & 23,039 \\
\hline 1996 & 37,439 & 0.34 & 0.11 & 57,508 & 29,517 \\
\hline 1997 & 40,598 & 0.34 & 0.13 & 53,765 & 34,150 \\
\hline 1998 & 41,400 & 0.34 & 0.14 & 51,444 & 35,601 \\
\hline 1999 & 43,834 & 0.35 & 0.16 & 45,477 & 41,465 \\
\hline 2000 & 51,562 & 0.35 & 0.16 & 54,753 & 48,357 \\
\hline 2001 & 53,887 & 0.35 & 0.18 & 53,538 & 52,152 \\
\hline 2002 & 59,672 & 0.36 & 0.15 & 71,460 & 52,720 \\
\hline 2003 & 69,476 & 0.39 & 0.14 & 94,725 & 58,199 \\
\hline 2004 & 82,716 & 0.40 & 0.12 & 125,537 & 67,417 \\
\hline 2005 & 96,256 & 0.40 & 0.18 & 98,887 & 91,493 \\
\hline 2006 & 113,227 & 0.41 & 0.19 & 112,181 & 108,608 \\
\hline 2007 & 142,510 & 0.46 & 0.14 & 192,451 & 119,512 \\
\hline 2008 & 182,380 & 0.46 & 0.12 & 253,868 & 152,749 \\
\hline 2009 & 183,764 & 0.42 & 0.15 & 232,194 & 157,787 \\
\hline 2010 & 208,926 & 0.45 & 0.15 & 248,176 & 187,535 \\
\hline 2011 & 248,747 & 0.46 & 0.14 & 260,395 & 236,438 \\
\hline 2012 & 275,061 & 0.43 & 0.17 & 216,480 & 287,653 \\
\hline 2013 & 310,713 & 0.45 & 0.16 & 254,792 & 318,943 \\
\hline 2014 & 340,996 & 0.45 & 0.16 & 269,913 & 354,430 \\
\hline 2015 & 365,879 & 0.47 & 0.15 & 317,181 & 369,132 \\
\hline
\end{tabular}

Source: Author's calculation from WDI (2016). Unit: billion VND.

Note: GDP: gross domestic product. C: final consumption expenditure. I: gross capital formation. M: import of goods and services. E: Export of goods and services. Unit: Vietnamese Dong (VND)

Figure 10: Contribution of Components of Aggregate Demand to GDP

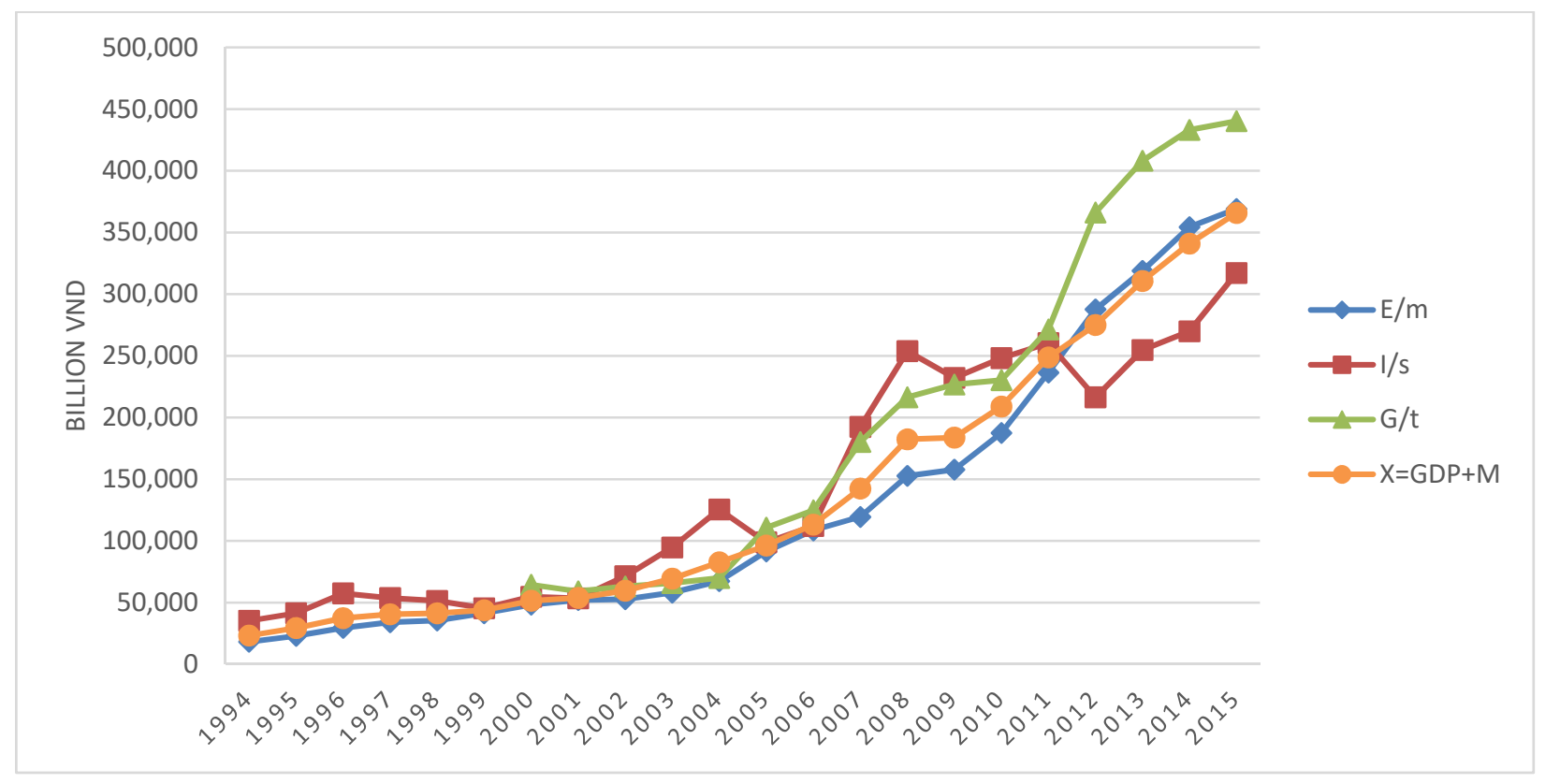


Figure 11: Sources of Demand: Direct Multiplier Effects minus Total Supply

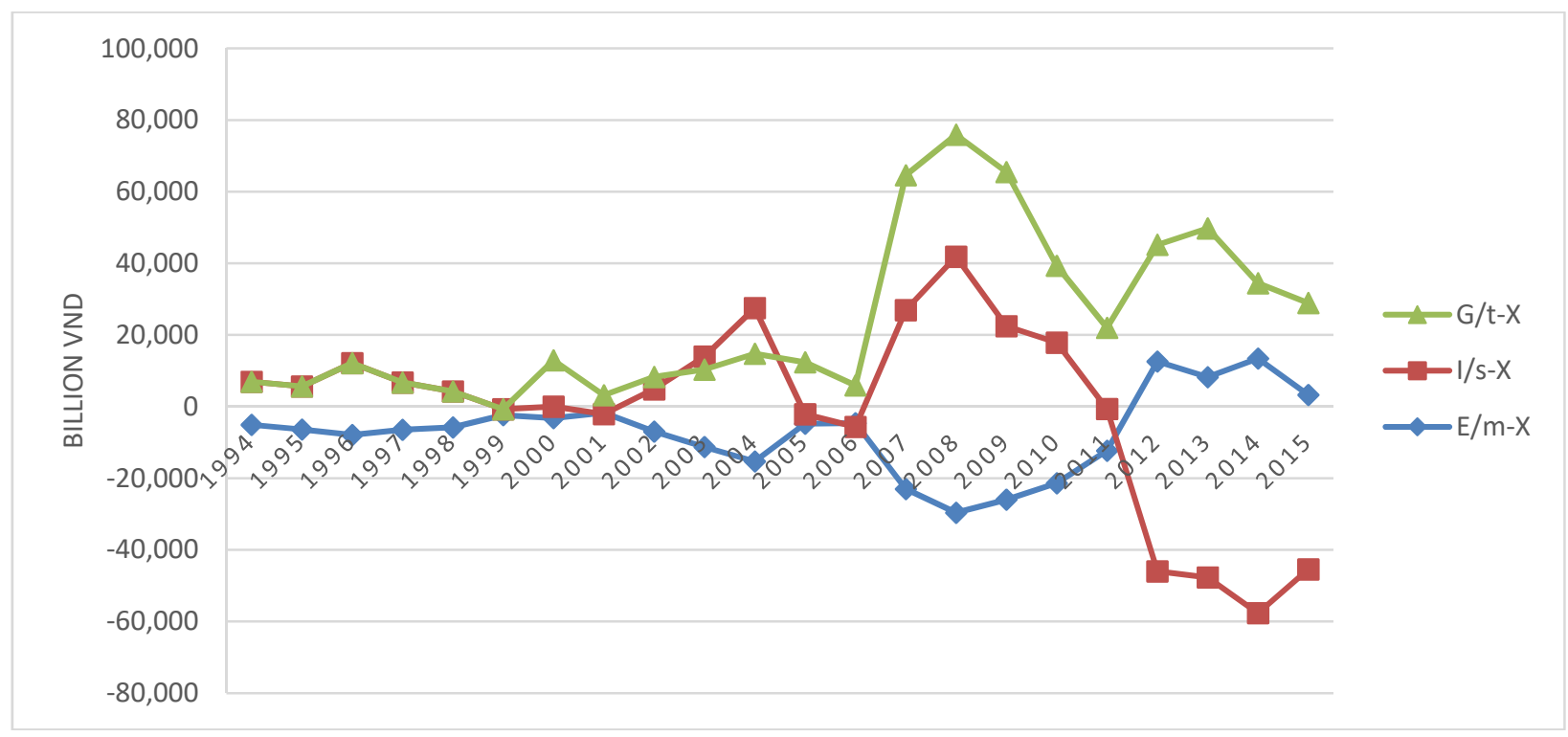

Figure 12: Leakages: Saving, Tax and Import Propensities

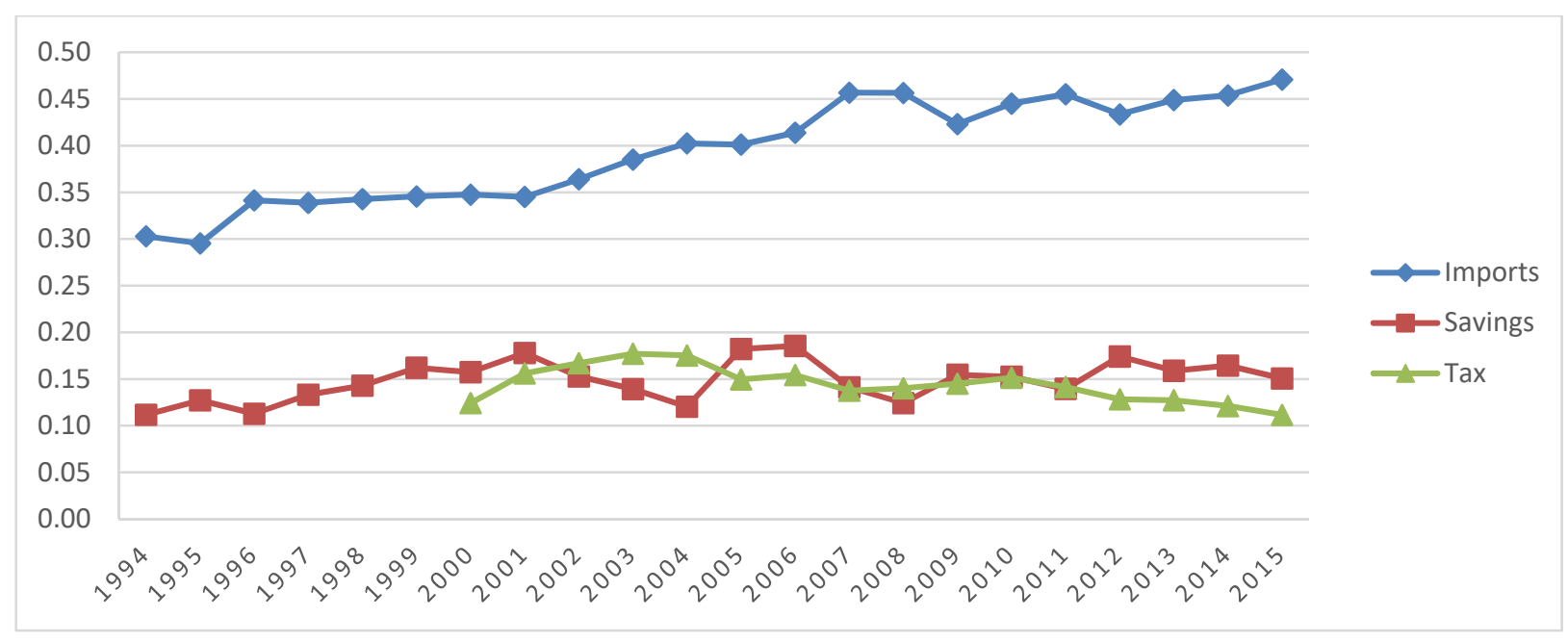

Figure 10 and Figure 11 indicate that Vietnamese economy has not shown a definitive export orientation during 1994-2011. The total supply (X) was always higher than the contribution of exports to GDP $(E / m)$ since 1994 to 2011. However, E/m has been higher than X since 2012, with a greater contribution of exports to the total supply or total output. With the Doi Moi policy reforms, Vietnam shifted the country to a more market-oriented economy, and the export of goods and services has been an important priority. However, Vietnam's economy has still been recovering from the impact of war, the collapses of Soviet Union Bloc, as well as from Asian economic crisis in 1997 and global financial crisis in 2008. The greater contribution of external sector since 2011 has convinced many that the liberal reform of Vietnamese government since Doi Moi was correct.

Figure 10 also suggests that private investment's contribution $(\mathrm{Ip} / \mathrm{s})$ was always greater than $\mathrm{X}$, and private investment a strong impetus to Vietnamese economic growth after Doi Moi until 2011. However, private investment has no longer been the main determinant of total output in Vietnam since 2012.

Between 1997 to 2005, there was a decline in government contribution to output due to the transition to a market- oriented system, the weak ability of the government to tax the emerging private sector. The contributions of state sector to government revenues has declined even as that of the private sector increased. Government budget rose after 2005 and become the main driving force of Vietnamese output since 2012. The 
increase from 7.2 percent to 12.2 percent annual growth rate in government spending from 2010 to 2015 (see Table 8) were offset by an increase in government revenues as a share of GDP.

In short, government spending and private investment were the main drivers of Vietnamese economic growth during 1994 - 2011, while the very high propensity of imports (Figure 2) led to the negative impact of exports on overall demand throughout this period. The external sector together with government expenditure have become the important driving factors of Vietnamese economic growth since 2012.

\section{Employment Changes and Decompositions of Labor Productivity Growth in Vietnam}

\subsection{The Decomposition Technique of Labor Productivity}

\subsubsection{The Decomposition Technique}

This section presents the decomposition of movements across sectors and time in labor productivity growth, as well as employment following Berg and Taylor (2000).

The decomposition is as follows:

$X$ is output, $L$ is employment, which $x$ and $l$ denote the growth rate of output and employment

respectively. Subscript $i$ denote the $\mathrm{i}^{\text {th }}$ sector. $\frac{X_{i}}{X}$ is share of sector $i$ output and $\frac{L_{i}}{L}$ represents the share of sector $i$ employment. Then labor productivity in sector $i$ is given by $\frac{X_{i}}{L_{i}}$ and the growth rate of labor productivity is $\varepsilon_{i}=x_{i}-l_{i}$. The growth rate of labor productivity for the whole economy is decomposed into two parts as the following:

$$
\varepsilon_{L}=\sum_{i}\left[\frac{X_{i}}{X} \varepsilon_{i}+\left(\frac{X_{i}}{X}-\frac{L_{i}}{L}\right) l_{i}\right]
$$

\subsubsection{Challenges of Measuring Labor Productivity in Service Sectors}

Labor productivity is defined as a ratio of a volume measure of output to a volume measure of input use and productivity measurement in manufacturing sector has been mostly based on comparing input and output (OECD, 2001). However, measuring the productivity of services has been challenging because of its difficulty in how to measure output and input.

The problem of measuring a service output is that the output indexes have to be quantifiable and independent of input indicators (Mark, 1982). For example, we cannot count boxes as the output for a day of a broker, an expediter or a quality control officer. We must find a way to quantify service output by measuring the number of services, number of customers or number of problems which are solved. There is quantity data available in some service sectors such as for utilities and transportation services. Price deflation may be used to measure output for gasoline service stations or retail food stores. The problem of measuring a service input is data gaps. Employment data, working hours by age and occupation of service sector are limited.

\subsection{Employment Growth and Changes in Employment Structure in Vietnam}

Since the adoption of its reform and opening-up policy, there has been a continuous growth in employment in Vietnam. The total of employed persons was 37.07 million in 2000 and up to 52.8 million after 15 years in 2015 (see Table 11). There are significant changes in the structure of employment in Vietnam in the past 10 years. As shown in Table II.10, the share of the total employed persons in the primary sector ${ }^{42}$ (AFF) has declined from 69 percent in 1999 to 55.1 percent in 2005 and to 44 percent in 2015, a reduction of 25 percent (GSO's website). Meanwhile, the employment shares

\footnotetext{
${ }^{42}$ The primary sector includes agriculture, forestry and fishing, and denoted as AFF.
} 
of other sectors such as manufacturing, construction and services have increased from 11.8 percent; 4.6 percent and 26.7 percent in 2005 to 15.3 percent; 6.5 percent and 32.5 percent in 2015 respectively. These trends reflect and are consistent with external liberalization in Vietnam during 2005-2015.

Table 9: Employment by Industry

\begin{tabular}{|l|c|c|c|c|c|c|c|c|c|c|}
\hline \multicolumn{1}{|c|}{ Year } & $\mathbf{2 0 0 5}$ & $\mathbf{2 0 0 7}$ & $\mathbf{2 0 0 8}$ & $\mathbf{2 0 0 9}$ & $\mathbf{2 0 1 0}$ & $\mathbf{2 0 1 1}$ & $\mathbf{2 0 1 2}$ & $\mathbf{2 0 1 3}$ & $\mathbf{2 0 1 4}$ & $\mathbf{2 0 1 5}$ \\
\hline Agriculture, forestry and fishing & 55.1 & 52.9 & 52.3 & 51.5 & 49.5 & 48.4 & 47.4 & 46.7 & 46.3 & 44 \\
(AFF) & 11.8 & 12.5 & 12.9 & 13.5 & 13.5 & 13.8 & 13.8 & 13.9 & 14.1 & 15.3 \\
Manufacturing & 4.6 & 5.2 & 5.3 & 5.4 & 6.3 & 6.4 & 6.4 & 6.3 & 6.3 & 6.5 \\
Construction & 26.7 & 27.7 & 28 & 28.2 & 29 & 29.9 & 30.8 & 31.3 & 31.7 & 32.5 \\
Services &
\end{tabular}

Source: GSO, unit: percentage

The share of the foreign investment sector in employment has increased in Vietnam. The share of total employed persons working in enterprises with foreign investment was 1 percent in 2000, and increased to 4.2 percent in 2015, which is consistent with trade-integration activities in Vietnam during the fifth and sixth phase of the Doi Moi Policy. Employment in the non-state sector remains high in Vietnam with the shares of 87.3 percent in 2000 and 86 percent in 2015 (Table 11) due to the massive restructuring of state-owned enterprises (SOEs) under the Doi Moi policy and the requirements of being an official member of WTO.

Table 10: Employment by Types of Ownership in Vietnam

\begin{tabular}{|c|c|c|c|c|}
\hline Year & Total (Thous. Persons) & State (\%) & Non-state (\%) & Foreign investment sector (\%) \\
\hline 2000 & $37,075.3$ & 11.7 & 87.3 & 1 \\
2001 & $38,180.1$ & 11.7 & 87.4 & 0.9 \\
2002 & $39,275.9$ & 11.8 & 87.1 & 1.1 \\
2003 & $40,403.9$ & 12.1 & 86 & 1.9 \\
2004 & $41,578.8$ & 12.1 & 85.7 & 2.2 \\
2005 & $42,774.9$ & 11.6 & 85.8 & 2.6 \\
2006 & $43,980.3$ & 11.2 & 85.8 & 3 \\
2007 & 45,208 & 10.9 & 85.5 & 3.5 \\
2008 & $46,460.8$ & 10.6 & 85.5 & 3.6 \\
2009 & $47,743.6$ & 10.4 & 86.2 & 3.5 \\
2010 & $49,048.5$ & 10.4 & 86.1 & 3.4 \\
2011 & 50,352 & 10.4 & 86.2 & 3.3 \\
2012 & $51,422.4$ & 10.2 & 86.3 & 3.4 \\
2013 & $52,207.8$ & 10.4 & 85.7 & 3.9 \\
2014 & $52,744.5$ & 9.8 & 86 & 4.2 \\
2015 & 52,840 & \multicolumn{2}{c}{} \\
\hline
\end{tabular}

Source: GSO

\subsection{Decomposition Results of Overall Labor Productivity Growth}

During every stage of the Doi Moi Policy and liberalization since 1986, foreign investment and the participation of domestic enterprises in international trade play a very important role in boosting domestic production as well as overall labor productivity. Labor productivity has increased impressively from 22.8 percent in 2005 to 23.8 percent in 2008 . However, it decreased to 5.84 percent in 2010 after the global financial crisis (see Table 14). There was an upward trend of the growth of labor productivity in 2011 thank to the stimulus package of the Vietnamese government. However, the growth rate of labor productivity has been declining since 2013 due to the crash of domestic stock market and, the banking and real estate sectors, as well as overwhelming number of business closures during the period of 2007-2012. Labor productivity grew at different rates in different sectors, and the service sector productivity was the fastest growing during the period 2005-2015. 
The decomposition of overall productivity in Table 12, Table 13 and Table 14 show that sectoral productivity growth, especially in the case of the service sector in 2005, 2008 and 2010, played an important role in the improvement of overall productivity in Vietnam (see Table13). Meanwhile, labor productivity of AFF and construction sectors remained lower. However, the AFF sector was still the second contributor to employment growth, although its labor share declined by 11 percent after 15 years (see Table 10). The decomposition also shows that in the fifth phase of the Doi Moi policy when the domestic economic market faced with the global financial crisis $(2008-2012)$ employment growth in manufacturing sector in 2011, 2013, 2014 and 2015 and construction sector in 2008, 2011 and 2012 (see Table 13) had a negative effect on overall productivity.

The decomposition indicates that sectoral productivity growth was the main driver of overall productivity in Vietnam from 2005-2015. The service sector accounted for significant sectoral productivity gains due to its large output share, while the employment reallocation of manufacturing, and construction sectors slowed down the productivity gains (see Table 12 and Table 13). We can link these results to the macroeconomic performance in Vietnam. Under the Doi Moi Policy and external liberalization, services have been attractive and profitable sectors thank to emerging demand in wholesaler, retailer, tourism and education as well as encouraging policies of the Vietnamese government on these sectors. There was a significant movement of labor into the services sector during the period 2005-2015. The employment share of service sector increased from 26.7 in 2005 to 32.5 in 2015 (see Table 10). However, the growth of output share in service sector was the highest rate compared to other sectors that contributed mainly to the sectoral productivity growth. Meanwhile, the contribution of the industry sector (manufacturing and construction) was unexpectedly weak because of the massive shifts from state-owned enterprises (SOEs) to private enterprises and their greater involvement in a more liberalized and competitive market. As a result, a large number of workers from SOEs shifted over to the private service sectors in urban areas during 2005-2015 and it became an important driver of employment growth in Vietnam. Moreover, the Doi Moi and opening-up policies have been bringing in more FDI during this period leading to new demand and labors for service sectors.

In short, the analysis of Vietnamese employment and the decomposition of labor productivity growth during 2005-2015 suggests that labor reallocation between sectors (AFF, manufacturing, construction and services) and growth in sectoral productivity are important. However, we should note that productivity gains from employment reallocation between sectors have not been particularly significant during this period, while sectoral productivity growth in service sector was the main driver of overall productivity growth.

Table 11: Contributions of Sectoral Productivity Growth to Overall Productivity

\begin{tabular}{|c|c|c|c|c|c|}
\hline \multirow{2}{*}{ Year } & \multirow{2}{*}{$\sum\left(\frac{X_{i}}{\boldsymbol{X}}\right) \boldsymbol{\varepsilon}_{\boldsymbol{i}}(\boldsymbol{\%})$} & \multicolumn{4}{|c|}{$\left(\frac{\boldsymbol{X}_{\boldsymbol{i}}}{\boldsymbol{X}}\right) \boldsymbol{\varepsilon}_{\boldsymbol{i}}$} \\
\cline { 3 - 6 } & & AFF (\%) & Manufacturing (\%) & Construction (\%) & Service (\%) \\
\hline $\mathbf{2 0 0 5}$ & 19.06 & 4.81 & 2.64 & 2.01 & 9.6 \\
$\mathbf{2 0 0 6}$ & 7.34 & 1.5 & 2.28 & 0.72 & 2.84 \\
$\mathbf{2 0 0 7}$ & 13.15 & 3.68 & 2.28 & 0.74 & 6.44 \\
$\mathbf{2 0 0 8}$ & 23.04 & 8.21 & 3.22 & 0.92 & 10.70 \\
$\mathbf{2 0 0 9}$ & 6.7 & 0.7 & 0.44 & 0.58 & 4.98 \\
$\mathbf{2 0 1 0}$ & 3.36 & 2.87 & -2.35 & 0.03 & 10.87 \\
$\mathbf{2 0 1 1}$ & 22.39 & 7.2 & 3.56 & 0.76 & 6.57 \\
$\mathbf{2 0 1 2}$ & 11.83 & 2.84 & 1.87 & 0.54 & 3.51 \\
$\mathbf{2 0 1 3}$ & 5.41 & 0.56 & 1.12 & 0.21 & 4.98 \\
$\mathbf{2 0 1 4}$ & 7.77 & 1.47 & 0.84 & 0.47 & 3.48 \\
$\mathbf{2 0 1 5}$ & 5.38 & 1.19 & 0.02 & 0.52 & \\
\hline
\end{tabular}

Source: Author's calculation based on Vietnamese Statistical Yearbook (various issues from 2005 to 2015) 
Table 12: Contributions to Employment Reallocation Effect on Overall Productivity Growth

\begin{tabular}{|c|c|c|c|c|c|}
\hline \multirow{2}{*}{ Year } & \multirow{2}{*}{$\sum\left(\frac{X_{i}}{X}-\frac{L_{i}}{L}\right) \boldsymbol{l}_{i}(\boldsymbol{\%})$} & \multicolumn{4}{|c|}{$\left(\frac{X_{i}}{X}-\frac{L_{i}}{L}\right) l_{i}$} \\
\hline & & AFF (\%) & Manufacturing (\%) & Construction (\%) & Service $(\%)$ \\
\hline 2005 & 3.379 & 0.639 & 1.2 & 0.14 & 1.4 \\
\hline 2006 & 2.364 & 1.344 & 0.32 & 0.08 & 0.62 \\
\hline 2007 & 1.01 & 0.06 & 0.12 & 0.73 & 0.1 \\
\hline 2008 & 0.76 & 0.36 & 0.18 & 0.02 & 0.2 \\
\hline 2009 & 0.72 & 0.5 & 0.22 & -0.01 & 0.01 \\
\hline 2010 & 2.12 & 1.21 & 0.01 & 0.1 & 0.8 \\
\hline 2011 & 0.81 & 0.64 & -0.01 & -0.02 & 0.2 \\
\hline 2012 & 0.98 & 0.58 & 0.01 & -0.01 & 0.4 \\
\hline 2013 & 0.63 & 0.42 & -0.01 & 0.02 & 0.2 \\
\hline 2014 & 0.21 & 0.2 & -0.01 & 0.01 & 0.01 \\
\hline 2015 & 1.47 & 1.34 & -0.01 & 0.13 & 0.01 \\
\hline
\end{tabular}

Source: Author's calculation based on Vietnamese Statistical Yearbook (various issues from 2005 to 2015)

Table 14: The Growth Rate of Overall Labor Productivity

\begin{tabular}{|c|c|c|c|}
\hline Year & $\varepsilon_{L}=\sum_{i}\left[\frac{X_{i}}{X} \varepsilon_{i}+\left(\frac{X_{i}}{X}-\frac{L_{i}}{L}\right) l_{i}\right](\boldsymbol{\%})$ & $\sum\left(\frac{X_{i}}{X}\right) \boldsymbol{\varepsilon}_{\boldsymbol{i}}(\boldsymbol{\%})$ & $\sum\left(\frac{X_{i}}{X}-\frac{\boldsymbol{L}_{\boldsymbol{i}}}{\boldsymbol{L}}\right) \boldsymbol{l}_{\boldsymbol{i}}(\boldsymbol{\%})$ \\
\hline $\mathbf{2 0 0 5}$ & 22.439 & 19.06 & 3.379 \\
$\mathbf{2 0 0 6}$ & 9.704 & 7.34 & 2.364 \\
$\mathbf{2 0 0 7}$ & 14.16 & 13.15 & 1.01 \\
$\mathbf{2 0 0 8}$ & 23.8 & 23.04 & 0.76 \\
$\mathbf{2 0 0 9}$ & 7.42 & 6.7 & 0.72 \\
$\mathbf{2 0 1 0}$ & 5.84 & 3.36 & 2.12 \\
$\mathbf{2 0 1 1}$ & 23.2 & 22.39 & 0.81 \\
$\mathbf{2 0 1 2}$ & 12.81 & 11.83 & 0.98 \\
$\mathbf{2 0 1 3}$ & 6.04 & 5.41 & 0.63 \\
$\mathbf{2 0 1 4}$ & 7.98 & 7.77 & 0.21 \\
$\mathbf{2 0 1 5}$ & 6.85 & 5.38 & 1.47 \\
\hline
\end{tabular}

Source: Author's calculation based on Vietnamese Statistical Yearbook (various issues from 2005-2015)

\section{Conclusions and Recommendations}

This essay attempts to investigate Vietnamese macroeconomic performance since its comprehensive reforms in 1986 (the Doi Moi Policy). It seeks to shed some light on the main driver of aggregate demand, employment and labor productivity. To this end, the author investigates the main mechanisms driving the remarkable performance of Vietnamese economy since the Doi Moi Policy. The author tried to explore factors resulting the upward trend in economic growth of Vietnam recently and elaborate the relationship between economic growth and the Doi Moi policy as well as external liberalization. The results of the decomposition of aggregate demand highlighted the following aspects:

- Private investment was the most important determinants of Vietnamese economic growth during 1994 - 2011, while government expenditure has contributed its influences on total output since 2005 .

- The very high propensity of imports had resulted in the negative stance of exports through the period of 1994-2011.

- The external sector together with government expenditure have become important driving factors of Vietnamese economic growth since 2012. 
The analysis of employment growth and the decomposition of overall labor productivity highlighted the following aspects:

- During the Doi Moi and opening-up policies, employment has grown dramatically in Vietnam, with the total of employed persons of 52.8 million in 2015. The share of total employed persons in the primary sector (agriculture, forestry and fishing - AFF) has declined while employment share of the foreign invested sectors has increased.

- The decomposition of labor productivity shows that that sectoral productivity growth, especially in the case of the service sector, plays an important role in the improvement of overall productivity in Vietnam.

- During the thirty years of the Doi Moi Policy and opening their economy, the income gap between regions and people in Vietnamese urban and rural areas has continued to be apparent however it has been narrowed.

The success of government's intensive reforms underlines the important role of government policies on Vietnamese economy. To continue benefiting from trade liberalization, Vietnamese government should preserve and extend their role in managing the market-oriented economy by formulating rules and regulations for the external sectors, while encouraging private investment. The State Bank of Vietnam should pursue a flexible of loosening or tightening monetary policy to ease pressure of high inflation and stabilize macroeconomic. Restructuring of commercial banking sectors and stabilizing exchange rate seem to be a necessary policy to maintain macroeconomic stability.

The decomposition of effective demand and labor productivity growth suggests that Vietnamese government should promote the private sector, which plays very important role in accelerating economic growth. This can be achieved by streamlining bureaucratic procedure for business start-up, giving private enterprises equal rights with state-owned companies, while removing any limitation to them to access to international market. Vietnamese government should encourage and support domestic enterprises in trading in the international market by more open regulations, intensive training and education for their employees as well as continuing the shift from state-owned enterprises to non-stated owned enterprises. Since the sectoral productivity growth of the service sector seems to be the most important driver of overall productivity growth in Vietnam during the past ten years, it would appear that the government should pay more attention on this sector by investing and building more infrastructure as well as improving regulations governing service activities. At the same time steps can be taken to improve productivity in the manufacturing sector which constitutes a significant share of employment. This is particularly important if Vietnam is to avoid premature deindustrialization that external liberalization has given rise to in many developing countries.

\section{References}

[1] Berg, J. and L. Taylor, 2000. "External Liberalization, Economic Performance, and Social Policy”, CEPA Working Paper Series I, Working Paper No12, February, New York: Center for Economic Policy Analysis.

[2] Bhatt, P.R., 2013. "Causal Relationship between Exports, FDI and Income: The Case of Vietnam", Applied Econometrics and International Development, Vol 13-1 (2013).

[3] Le, A.T. Parkard, 2006. "Vietnam: External Liberalization, Structural Change, Economic Growth, and Income Distribution", in "External Liberalization in Asia, Post-Socialist Europe, and Brazil", Lance Taylor, Oxford University Press (2006).

[4] Keough, A., 2016. "Reform of Die: Doi Moi, TPP and the Legitimacy of Power in Vietnam", Journal of Political Inquiry, Fall 2016.

[5] Mark, J., 1982. "Measuring Productivity in Service Industries", Monthly Labor Review.

[6] Nguyen, D., Tu, A. and P. Chu, 2012. "On the Linkage between FDI and Trade: Evidence from Vietnam", SECO/WTI Academic Cooperation Project, Working Paper, Series 5/2012.

[7] OECD, 2001. "Measuring Productivity", OECD Manual. 
[8] Tran, Q and P. To, 2000. "The Doi Moi Policy and Its Impacts on the Poor", Centre for Gender, Environment and Sustainable Development Studies (GENDCEN).

[9] Tsuboi, Y., 2007. "Twenty Years After the Adoption of the Doi Moi Policy", Discussion Paper, Graduate School of Political Science, Waseda University.

[10] Vandemoortele and Bird, 2011. "Vietnam's Progress on Economic Growth and Poverty Reduction: Impressive Improvements", ODI publications, 111 Westminster Bridge Road, London SE1 7JD, UK.

[11] Vuong, Q., 2014: "Vietnam's Political Economy: A Discussion on the 1986-2016 period", CEB Working Paper, N0 14/010, May 2014.

Table A.II. 1: Monthly Average Income Per Capita at Current Prices by Income Source

\begin{tabular}{|c|c|c|c|c|c|c|c|c|c|c|c|c|c|c|c|}
\hline Year & \multicolumn{5}{|c|}{2010} & \multicolumn{5}{|c|}{2012} & \multicolumn{5}{|c|}{2014} \\
\hline Types & Total & $\begin{array}{l}\text { Salary } \\
\text { \& wage }\end{array}$ & $\mathbf{A F F}^{43}$ & $\begin{array}{l}\text { Non- } \\
\text { AFF }\end{array}$ & Others & Total & $\begin{array}{l}\text { Salary } \\
\text { \& wage }\end{array}$ & AFF & $\begin{array}{l}\text { Non- } \\
\text { AFF }\end{array}$ & Others & Total & $\begin{array}{l}\text { Salary } \\
\text { \& wage }\end{array}$ & AFF & $\begin{array}{l}\text { Non- } \\
\text { AFF }\end{array}$ & Others \\
\hline \begin{tabular}{|l} 
Whole Country \\
\end{tabular} & 1387 & 622 & 279 & 328 & 158 & 2000 & 923 & 397 & 442 & 238 & 2637 & 1253 & 458 & 591 & 335 \\
\hline Red River Delta & 1580 & 798 & 189 & 392 & 201 & 2351 & 1216 & 275 & 556 & 304 & 3265 & 1733 & 327 & 738 & 467 \\
\hline Ha Noi & 2013 & 1165 & 109 & 467 & 273 & 2945 & 1741 & 169 & 657 & 378 & 4113 & 2537 & 226 & 767 & 583 \\
\hline Vinh Phuc & 1232 & 519 & 256 & 317 & 140 & 1867 & 784 & 373 & 517 & 193 & 2378 & 1089 & 342 & 645 & 302 \\
\hline Bac Ninh & 1646 & 560 & 190 & 707 & 189 & 2502 & 875 & 256 & 1089 & 281 & 3512 & 1178 & 299 & 1641 & 394 \\
\hline Quang Ninh & 1787 & 895 & 176 & 533 & 183 & 2557 & 1367 & 224 & 626 & 340 & 3053 & 1580 & 308 & 795 & 370 \\
\hline Hai Duong & 1306 & 600 & 258 & 286 & 163 & 2047 & 996 & 377 & 415 & 259 & 2755 & 1289 & 433 & 651 & 382 \\
\hline Hai Phong & 1694 & 958 & 115 & 418 & 204 & 2526 & 1278 & 197 & 590 & 461 & 3923 & 2002 & 314 & 862 & 745 \\
\hline Hung Yen & 1199 & 522 & 261 & 275 & 141 & 1803 & 785 & 412 & 445 & 161 & 2192 & 998 & 429 & 492 & 273 \\
\hline Thai Binh & 1129 & 518 & 251 & 216 & 143 & 1729 & 878 & 368 & 299 & 184 & 2469 & 1214 & 384 & 476 & 395 \\
\hline Ha Nam & 1150 & 470 & 264 & 248 & 168 & 1754 & 710 & 374 & 440 & 230 & 2198 & 917 & 389 & 544 & 348 \\
\hline Nam Dinh & 1237 & 477 & 286 & 322 & 153 & 1791 & 769 & 379 & 423 & 220 & 2816 & 1280 & 446 & 718 & 372 \\
\hline Ninh Binh & 1202 & 498 & 264 & 280 & 160 & 1696 & 762 & 355 & 289 & 290 & 2215 & 1092 & 437 & 386 & 300 \\
\hline $\begin{array}{l}\text { Northern } \\
\text { midlands and }\end{array}$ & 905 & 359 & 314 & & & & 536 & & & & 1613 & & 471 & & 152 \\
\hline $\begin{array}{l}\text { midlands and } \\
\text { mountain areas }\end{array}$ & 905 & 359 & 314 & 140 & 86 & 1258 & 550 & 406 & 191 & 119 & 1013 & 101 & $4 / 1$ & 283 & 152 \\
\hline Ha Giang & 610 & 193 & 317 & 61 & 38 & 850 & 274 & 440 & 76 & 60 & 1121 & 367 & 507 & 157 & 90 \\
\hline Cao Bang & 749 & 312 & 293 & 83 & 61 & 1054 & 453 & 402 & 112 & 87 & 1252 & 590 & 403 & 112 & 147 \\
\hline Bac Kan & 776 & 266 & 311 & 135 & 65 & 1142 & 313 & 481 & 290 & 58 & 1216 & 410 & 500 & 220 & 86 \\
\hline Tuyen Quang & 887 & 348 & 344 & 125 & 70 & 1162 & 472 & 410 & 194 & 86 & 1571 & 683 & 498 & 243 & 147 \\
\hline Lao Cai & 819 & 345 & 324 & 105 & 45 & 1085 & 527 & 311 & 183 & 64 & 1468 & 644 & 411 & 345 & 68 \\
\hline Yen Bai & 844 & 373 & 273 & 119 & 79 & 1114 & 520 & 326 & 187 & 81 & 1386 & 590 & 421 & 262 & 113 \\
\hline Thai Nguyen & 1149 & 504 & 282 & 253 & 110 & 1747 & 869 & 397 & 350 & 132 & 2238 & 1087 & 473 & 526 & 152 \\
\hline Lang Son & 929 & 367 & 342 & 169 & 52 & 1212 & 475 & 468 & 202 & 68 & 1437 & 635 & 494 & 214 & 94 \\
\hline Bac Giang & 1103 & 406 & 344 & 196 & 157 & 1568 & 668 & 473 & 235 & 192 & 2174 & 995 & 550 & 378 & 251 \\
\hline Phu Tho & 1126 & 519 & 228 & 244 & 135 & 1579 & 754 & 311 & 294 & 219 & 1954 & 940 & 389 & 327 & 298 \\
\hline Dien Bien & 611 & 196 & 306 & 61 & 48 & 819 & 364 & 323 & 52 & 80 & 1200 & 450 & 420 & 235 & 95 \\
\hline Lai Chau & 567 & 205 & 255 & 59 & 48 & 758 & 237 & 337 & 120 & 64 & 987 & 373 & 390 & 137 & 87 \\
\hline Son La & 802 & 224 & 444 & 86 & 48 & 1020 & 257 & 541 & 108 & 113 & 1178 & 400 & 565 & 149 & 64 \\
\hline Hoa Binh & 829 & 379 & 286 & 85 & 79 & 1219 & 570 & 404 & 136 & 110 & 1598 & 707 & 459 & 279 & 153 \\
\hline Northern & & & & & & & & & & & & & & & \\
\hline $\begin{array}{l}\text { Central area } \\
\text { and Central }\end{array}$ & 1018 & 442 & 231 & 229 & 116 & 1505 & 679 & 320 & 343 & 163 & 1982 & 923 & 379 & 440 & 240 \\
\hline Thanh Hoa & 840 & 364 & 245 & 151 & 81 & 1207 & 545 & 294 & 248 & 120 & 1635 & 831 & 368 & 251 & 185 \\
\hline Nghe An & 920 & 391 & 246 & 136 & 147 & 1367 & 564 & 351 & 240 & 212 & 1583 & 657 & 367 & 307 & 252 \\
\hline Ha Tinh & 840 & 336 & 214 & 147 & 142 & 1299 & 554 & 364 & 238 & 143 & 1810 & 831 & 372 & 320 & 287 \\
\hline Quang Binh & 950 & 447 & 201 & 168 & 135 & 1410 & 735 & 268 & 227 & 180 & 1837 & 939 & 313 & 386 & 199 \\
\hline Quang Tri & 951 & 381 & 257 & 232 & 80 & 1300 & 521 & 390 & 231 & 158 & 1673 & 732 & 370 & 380 & 191 \\
\hline Thua Thien-Hue & 1058 & 439 & 174 & 342 & 104 & 1747 & 834 & 221 & 496 & 196 & 2175 & 993 & 263 & 672 & 247 \\
\hline Da Nang & 1897 & 1106 & 62 & 507 & 223 & 2865 & 1507 & 75 & 904 & 379 & 3612 & 1954 & 41 & 1186 & 431 \\
\hline Quang Nam & 935 & 411 & 213 & 205 & 107 & 1376 & 649 & 288 & 306 & 133 & 1784 & 885 & 337 & 379 & 183 \\
\hline Quang Ngai & 909 & 350 & 200 & 262 & 97 & 1300 & 571 & 239 & 356 & 134 & 1619 & 734 & 295 & 389 & 201 \\
\hline Binh Dinh & 1150 & 429 & 272 & 329 & 119 & 1719 & 717 & 414 & 447 & 141 & 2346 & 1005 & 531 & 509 & 301 \\
\hline Phu Yen & 1013 & 398 & 302 & 228 & 86 & 1440 & 650 & 402 & 309 & 79 & 1979 & 833 & 640 & 362 & 144 \\
\hline Khanh Hoa & 1258 & 650 & 217 & 269 & 121 & 1896 & 961 & 278 & 468 & 189 & 2670 & 1452 & 258 & 616 & 344 \\
\hline Ninh Thuan & 947 & 361 & 228 & 278 & 81 & 1637 & 722 & 403 & 366 & 146 & 2331 & 897 & 536 & 677 & 221 \\
\hline Binh Thuan & 1160 & 430 & 335 & 287 & 108 & 1747 & 667 & 504 & 431 & 145 & 2395 & 891 & 736 & 564 & 204 \\
\hline $\begin{array}{l}\text { Central } \\
\text { Highlands }\end{array}$ & 1088 & 334 & 470 & 217 & 67 & 1643 & 497 & 759 & 294 & 94 & 2008 & 678 & 863 & 350 & 117 \\
\hline Kon Tum & 947 & 384 & 307 & 186 & 70 & 1294 & 604 & 363 & 258 & 69 & 1587 & 710 & 445 & 294 & 138 \\
\hline Gia Lai & 1027 & 360 & 386 & 229 & 52 & 1563 & 483 & 659 & 341 & 80 & 1760 & 661 & 699 & 318 & 82 \\
\hline
\end{tabular}

${ }^{43} \mathrm{AFF}$ is agriculture, forestry \& fishery 


\begin{tabular}{|c|c|c|c|c|c|c|c|c|c|c|c|c|c|c|c|}
\hline Year & \multicolumn{5}{|c|}{2010} & \multicolumn{5}{|c|}{2012} & \multicolumn{5}{|c|}{2014} \\
\hline Types & Total & $\begin{array}{l}\text { Salary } \\
\text { \& wage }\end{array}$ & $A F F^{43}$ & $\begin{array}{l}\text { Non- } \\
\text { AFF }\end{array}$ & Others & Total & \begin{tabular}{|l|} 
Salary \\
\& wage
\end{tabular} & AFF & $\begin{array}{l}\text { Non- } \\
\text { AFF }\end{array}$ & Others & Total & \begin{tabular}{|l|} 
Salary \\
\& wage
\end{tabular} & AFF & $\begin{array}{l}\text { Non- } \\
\text { AFF }\end{array}$ & Others \\
\hline Dak Lak & 1068 & 312 & 496 & 193 & 67 & 1639 & 483 & 817 & 241 & 98 & 1988 & 600 & 937 & 332 & 119 \\
\hline Dak Nong & 1039 & 207 & 652 & 141 & 38 & 1611 & 372 & 994 & 179 & 66 & 1824 & 466 & 1064 & 207 & 87 \\
\hline Lam Dong & 1257 & 372 & 508 & 282 & 95 & 1848 & 537 & 824 & 367 & 120 & 2499 & 878 & 982 & 485 & 154 \\
\hline South East & 2304 & n.a. & n.a. & n.a. & n.a. & 3173 & 1709 & 361 & 725 & 377 & 4125 & 2247 & 344 & 1022 & 512 \\
\hline Binh Phuoc & 1526 & 514 & 641 & 270 & 101 & 2218 & 802 & 1003 & 313 & 100 & 2693 & 998 & 1076 & 469 & 150 \\
\hline Tay Ninh & 1435 & 494 & 516 & 312 & 113 & 2100 & 886 & 616 & 431 & 167 & 2796 & 1155 & 584 & 754 & 303 \\
\hline Binh Duong & 2698 & 1100 & 710 & 753 & 135 & 3568 & 1514 & 1109 & 774 & 171 & 3769 & 1773 & 825 & 937 & 234 \\
\hline Dong Nai & 1763 & 862 & 301 & 398 & 203 & 2577 & 1247 & 432 & 635 & 263 & 3504 & 1742 & 488 & 882 & 392 \\
\hline $\begin{array}{l}\text { Ba Ria - Vung } \\
\text { Tau }\end{array}$ & 1695 & 875 & 217 & 442 & 161 & 2904 & 1580 & 408 & 623 & 293 & 3752 & 1647 & 535 & 1245 & 325 \\
\hline $\begin{array}{l}\text { Ho Chi Minh } \\
\text { city }\end{array}$ & 2737 & 1613 & 30 & 745 & 348 & 3653 & 2205 & 21 & 870 & 557 & 4840 & 2925 & 37 & 1161 & 717 \\
\hline $\begin{array}{l}\text { Mekong River } \\
\text { Delta }\end{array}$ & 1247 & n.a. & n.a. & n.a. & n.a. & 1797 & 598 & 539 & 402 & 257 & 2327 & 783 & 674 & 528 & 342 \\
\hline Long An & 1289 & 520 & 369 & 230 & 170 & 1956 & 813 & 569 & 335 & 239 & 2430 & 1035 & 633 & 447 & 315 \\
\hline Tien Giang & 1313 & 440 & 369 & 331 & 172 & 1941 & 773 & 493 & 404 & 271 & 2596 & 1049 & 656 & 560 & 331 \\
\hline Ben Tre & 1200 & 348 & 353 & 318 & 180 & 1580 & 505 & 522 & 363 & 190 & 2162 & 705 & 649 & 442 & 366 \\
\hline Tra Vinh & 1089 & 313 & 373 & 258 & 144 & 1398 & 433 & 377 & 266 & 322 & 2098 & 739 & 703 & 361 & 295 \\
\hline Vinh Long & 1239 & 377 & 357 & 319 & 186 & 1744 & 601 & 446 & 400 & 297 & 2205 & 802 & 593 & 418 & 392 \\
\hline Dong Thap & 1138 & 382 & 356 & 243 & 158 & 1666 & 536 & 539 & 377 & 214 & 2134 & 741 & 661 & 439 & 293 \\
\hline An Giang & 1319 & 406 & 378 & 417 & 118 & 1871 & 546 & 498 & 548 & 279 & 2472 & 738 & 572 & 771 & 391 \\
\hline Kien Giang & 1316 & 441 & 408 & 294 & 173 & 1963 & 641 & 656 & 396 & 270 & 2642 & 795 & 828 & 571 & 448 \\
\hline Can Tho & 1540 & 642 & 282 & 436 & 180 & 2325 & 933 & 411 & 620 & 361 & 2673 & 1074 & 359 & 895 & 345 \\
\hline Hau Giang & 1098 & 332 & 343 & 259 & 164 & 1527 & 445 & 483 & 285 & 314 & 2088 & 482 & 633 & 541 & 432 \\
\hline Soc Trang & 1029 & 289 & 427 & 229 & 84 & 1324 & 421 & 445 & 317 & 141 & 1913 & 582 & 648 & 436 & 247 \\
\hline Bac Lieu & 1273 & 304 & 580 & 227 & 162 & 2035 & 406 & 992 & 393 & 244 & 2214 & 515 & 1093 & 339 & 267 \\
\hline Ca Mau & 1250 & 315 & 531 & 245 & 159 & 1779 & 502 & 673 & 366 & 238 & 2154 & 564 & 914 & 388 & 288 \\
\hline
\end{tabular}

